\title{
Comorbidity and lifestyle, reproductive factors, and environmental exposures associated with rheumatoid arthritis
}

\author{
Å Reckner Olsson, T Skogh, G Wingren
}

\begin{abstract}
Objective-To evaluate the influence of lifestyle, reproduction, and some external factors on the development of rheumatoid arthritis (RA) and to describe its comorbidity.

Methods-Cases were identified retrospectively from 1980 to 1995 at the University Hospital in Linköping, Sweden. The study comprised 422 cases and 859 randomly selected population referents. Data on possible aetiological factors and comorbidity were collected by postal questionnaire.
\end{abstract}

Results-The response rates were $67 \%$ among cases and $59 \%$ among referents. A decrease in the occurrence of atopic allergy was seen in the cases (odds ratio (OR) $0.6,95 \%$ confidence interval (CI) 0.4 to 1.0). There was a positive association between RA and insulin treatment (OR $10.2,95 \%$ CI 1.7 to 60.8 ) in women, and women with a short fertile period had an increased risk of RA (OR 2.5, 95\% CI 1.1 to 5.4). Current and previous smoking were associated with increased risks for RA in both sexes, and in men a dose-response relationship was found with number of tobacco pack years ( $p$ for trend $<0.005$ ). The risk for RA decreased with increasing level of education in both men and women. Increased risks were seen in men born into households with private wells (OR 2.8, 95\% CI 1.5 to 5.2), residentially exposed to mould (OR 4.6, 95\% CI 1.1 to 20.2), or exposed to farm animals (OR 3.3, $95 \%$ CI 0.7 to 16.6 ). In women there were positive associations between $R A$ and reporting a previous joint injury (OR 2.5, $95 \% \mathrm{CI} 1.0$ to 6.6 ) and prolonged exposure to hair dyes (OR 1.9, 95\% CI 0.8 to 4.5 ).

Conclusions-RA, a disease with features of $T$ helper 1 (Th1) dominated immune response, was inversely associated with atopic allergy, a Th2 dominated condition, while there were indications of a strong positive association with Th1 related diabetes mellitus. The results support a causal relationship between smoking and RA. The level of education was inversely associated with RA, while there was a positive association between RA and certain residential factors in men and a short fertile period in women.

(Ann Rheum Dis 2001;60:934-939)
Rheumatoid arthritis (RA) is a disorder of unknown aetiology. The susceptibility for RA probably varies between individuals as a result of genetic ${ }^{1}$ and hormonal ${ }^{2}$ factors, and the mechanisms underlying RA are complex and depend on a number of internal and external factors. RA has features of an organ specific autoimmune disease with a $\mathrm{T}$ helper 1 (Th1) dominated immune response, ${ }^{3}$ and it has been anticipated that an antigen driven immune response is required to perpetuate the disease, although the crucial antigen(s) have not been identified. Considering the functional dichotomy between Th1 and Th2 type responses, ${ }^{4}$ it is conceivable that other Th1 mediated autoimmune diseases could be overrepresented in patients with RA whereas an inverse relationship could be expected between RA and Th2 mediated conditions. Indeed, previous studies have supported a positive association between RA and, for example, thyroiditis, ${ }^{5}$ and a negative association between RA and atopy. $^{6-8}$

Despite the female preponderance, ${ }^{9}$ oestrogen and progesterone seem to have a suppressive effect on RA disease mechanisms. The highest incidence of RA in women occurs after menopause $^{9}$ when the levels of sex hormones decrease. Even so, the female preponderance is least pronounced in the older age group because of an increased incidence of RA in men ${ }^{9}$ which may be related to lower testosterone levels with increasing age. ${ }^{2}$ There are also indications of a primary hypoandrogenicity in both men and women with RA. ${ }^{2}$ Hyperprolactinaemia during breast feeding, for example, is known to stimulate Th1 mediated immunity, ${ }^{2}$ and a genetic linkage between human leucocyte antigen (HLA)-DR genes and genes regulating prolactin levels has been suggested. ${ }^{10}$ In rats the female preponderance for RA seems to be associated with a sex chromosome gene which may act together with female sex steroid hormones. ${ }^{11}$

Possible external contributions to the disease process in RA include lifestyle factors such as smoking $^{12-14}$ and alcohol, ${ }^{15}$ as well as infectious agents, ${ }^{16}$ occupational exposures, ${ }^{17}$ and exposure to pets. ${ }^{18}$ Furthermore, the relationship between RA and educational level, ${ }^{13}$ certain surgical procedures, ${ }^{19}$ and major life events ${ }^{20}$ has been studied.

The aim of this study was to evaluate the influence of lifestyle, reproductive, and environmental factors on the development of RA and to describe its comorbidity. 
Table 1 Case-referent evaluations of smoking habits in men (102 cases of $R A$ and 248 referents) and women (179 cases of $R A$ and 259 referents) from southeastern Sweden, 1980-95, with adjustment for age and socioeconomic status. ORs from separate analyses of 83 men and 134 women who were rheumatoid factor $(R F)$ positive are also shown. Never users of tobacco are regarded as unexposed

\begin{tabular}{|c|c|c|c|c|c|c|}
\hline & \multicolumn{3}{|l|}{ All cases } & \multicolumn{3}{|l|}{ Seropositive cases } \\
\hline & $\begin{array}{l}\text { Exposed } \\
\text { cases/referents }\end{array}$ & $O R^{\star}$ & $95 \% C I^{\star}$ & $\begin{array}{l}\text { Exposed } \\
\text { cases/referents }\end{array}$ & $O R^{\star}$ & $95 \% C I^{\star}$ \\
\hline \multicolumn{7}{|l|}{ Men } \\
\hline \multicolumn{7}{|c|}{ Pack years of smoking† } \\
\hline Non-smokers & $20 / 81$ & 1.0 & Reference & $14 / 81$ & 1.0 & Reference \\
\hline$<5$ & $2 / 19$ & 0.4 & 0.0 to 2.3 & $1 / 19$ & 0.2 & 0.0 to 1.8 \\
\hline $5-9$ & $7 / 22$ & 1.4 & 0.4 to 4.7 & $6 / 22$ & 1.5 & 0.4 to 5.7 \\
\hline $10-19$ & $28 / 37$ & 2.4 & 1.0 to 6.1 & $23 / 37$ & 2.4 & 0.9 to 6.6 \\
\hline$\geqslant 20$ & $\begin{array}{l}34 / 44 \\
\mathrm{p} \text { for trend }<0.010\end{array}$ & 2.7 & 1.2 to 5.8 & $\begin{array}{l}30 / 44 \\
\mathrm{p} \text { for trend }<0.005\end{array}$ & 3.4 & 1.5 to 8.4 \\
\hline \multicolumn{7}{|l|}{ Women } \\
\hline \multicolumn{7}{|c|}{ Pack years of smoking $\dagger$} \\
\hline Non-smokers & $88 / 145$ & 1.0 & Reference & $58 / 145$ & 1.0 & Reference \\
\hline$<5$ & $13 / 16$ & 1.8 & 0.7 to 4.4 & $11 / 16$ & 2.0 & 0.8 to 5.2 \\
\hline $5-9$ & $19 / 24$ & 1.5 & 0.7 to 3.2 & $15 / 24$ & 1.7 & 0.7 to 3.9 \\
\hline $10-19$ & $21 / 24$ & 1.5 & 0.7 to 3.2 & $17 / 24$ & 1.8 & 0.8 to 3.8 \\
\hline$\geqslant 20$ & $\begin{array}{l}13 / 13 \\
p \text { for trend }=0.113\end{array}$ & 1.8 & 0.7 to 4.6 & $\begin{array}{l}12 / 13 \\
\mathrm{p} \text { for trend }=0.029\end{array}$ & 2.5 & 0.9 to 6.7 \\
\hline
\end{tabular}

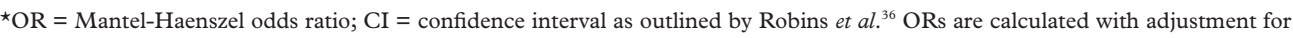
age.

†Mean number of packs per day multiplied by the total number of years of smoking.

\section{Methods}

SUBJECTS

Medical records of patients attending the Division of Rheumatology at the University Hospital in Linköping in 1995 were used to identify prevalent cases of RA. Cases were required to fulfil the American Rheumatism Association (ARA) 1987 revised criteria for the classification of $\mathrm{RA}^{21}$ and to be aged 25-75 years during the study period which extended from 1 January 1980 to 30 June 1995 . Four hundred and thirty two cases fulfilled the inclusion criteria.

The degree of recruitment of cases was likely to vary within the catchment area of the hospital since there are other smaller health care units in the most distant parts of the area. The study base was therefore defined by the postal zip codes of cases at the time of diagnosis. For each year of the study period twice as many referents as diagnosed cases in the same age range and living in the specified area were randomly enrolled. The referents were thus frequency matched but not individually matched to the cases. All referents were given a year of enrolment - that is, a dummy date corresponding to the year of diagnosis for cases. This retrospective selection of referents was possible because of the availability of historical population registers in Sweden. Cases and referents born outside the Nordic countries were excluded.

All but three referents could be traced to current addresses. A questionnaire, pretested in a pilot study, was mailed to all subjects in 1996. The postal questionnaire comprised various questions concerning possible aetiological and disease modifying determinants including lifestyle and reproductive factors, educational background, residential exposures to power lines, private wells and porous concrete in home walls, leisure time exposures, domestic animals, medication, trauma, and psychosocial stress. There were also questions concerning comorbidity. Questions covering occupational history have previously been evaluated and are presented in a separate report. ${ }^{22}$

Before analysis 10 cases and five referents who were found not to fulfil the inclusion criteria were excluded. Two referents had stated having RA which was diagnosed before their year of enrolment. The final study population therefore comprised 422 cases and 859 referents.

\section{DATA ANALYSIS}

The associations between RA and possible aetiological factors as well as comorbidity were evaluated by general principles for casereferent studies using the computer program EPI INFO (EPI INFO 6.04, Center for Disease Control and Prevention (CDC), USA). The material was analysed separately for men and women stratified into three age groups: $25-40$, $41-55$, and $56-75$ years of age at the time of diagnosis for cases and at the year of enrolment for referents. When relevant, the material was also stratified into three smoking categories (non-smokers, past or present occasional smokers, and past or present regular smokers), and for some analyses stratification was also made for occupation, marital status, and socioeconomic status.

The results are presented for assessments of a priori hypotheses based on earlier findings from the literature. New associations are presented when the number of exposed subjects was at least 10 and the risk estimate was $\geqslant 1.5$ or $\leqslant 0.5$, or otherwise significantly different from unity. Analyses were performed on the association between the start of exposure and the year of diagnosis according to the ARA for cases, and the year of dummy date of onset for referents. When considered relevant, analyses were also performed to examine the association between start of exposure and year of onset of symptoms for cases. Exposures occurring after these dates were disregarded. To be regarded as exposed, subjects were required to have a minimum duration of exposure of 6 months. 
Table 2 Case-referent evaluations of comorbidity, infections, education and some environmental exposures in women (179 cases of $R A$ and 259 referents) from southeastern Sweden, 1980-95, with adjustment for age

\begin{tabular}{|c|c|c|c|}
\hline & $\begin{array}{l}\text { Exposed } \\
\text { cases/referents }\end{array}$ & $O R^{\star}$ & $95 \% C I^{\star}$ \\
\hline \multicolumn{4}{|l|}{ Weight } \\
\hline BMI 26† & $12 / 10$ & 1.7 & 0.7 to 4.1 \\
\hline \multicolumn{4}{|l|}{ Comorbidity } \\
\hline Asthma & $12 / 12$ & 1.2 & 0.5 to 2.8 \\
\hline Allergy & $27 / 49$ & 0.7 & 0.4 to 1.2 \\
\hline Eczema & $8 / 31$ & 0.4 & 0.2 to 0.8 \\
\hline Endocrine diseases & $15 / 11$ & 2.2 & 1.0 to 5.1 \\
\hline Thyroid conditions & $11 / 5$ & 3.5 & 1.1 to 10.8 \\
\hline \multicolumn{4}{|l|}{ Medication } \\
\hline Insulin & $5 / 2$ & 10.2 & 1.7 to 60.8 \\
\hline \multicolumn{4}{|l|}{ Infections } \\
\hline Urinary tract infections & $40 / 90$ & 0.6 & 0.4 to 0.9 \\
\hline Rubella & $65 / 116$ & 0.6 & 0.4 to 1.0 \\
\hline Pneumonia & $36 / 31$ & 2.0 & 1.2 to 3.4 \\
\hline Tick-borne infections & $6 / 2$ & 4.6 & 0.9 to 23.1 \\
\hline \multicolumn{4}{|l|}{ Trauma } \\
\hline Joint injury 20 years ago & $12 / 7$ & 2.5 & 1.0 to 6.6 \\
\hline \multicolumn{4}{|l|}{ Educational level $\ddagger$} \\
\hline Compulsory school & $75 / 80$ & 1.0 & - \\
\hline Continuation/vocational school & $48 / 61$ & 1.1 & 0.6 to 1.8 \\
\hline Secondary/upper secondary school & $14 / 36$ & 0.5 & 0.2 to 1.1 \\
\hline University & $35 / 73$ & 0.5 & 0.3 to 0.9 \\
\hline \multicolumn{4}{|l|}{ Environmental exposures } \\
\hline Private well at birth $₫$ & $89 / 101$ & 1.5 & 0.9 to 2.4 \\
\hline Mould & $5 / 13$ & 0.5 & 0.2 to 1.4 \\
\hline Horses $\llbracket$ & $21 / 17$ & 4.2 & 0.5 to 37.8 \\
\hline Hair dyes/bleach for 20 years ${ }^{\star \star}$ & $17 / 10$ & 1.9 & 0.8 to 4.5 \\
\hline Solvents & $5 / 5$ & 1.5 & 0.4 to 5.1 \\
\hline \multicolumn{4}{|l|}{ Psychosocial stress } \\
\hline Matrimonial quarrels $\dagger \dagger$ & $7 / 2$ & 8.8 & 1.6 to 47.6 \\
\hline Matrimonial quarrels㧊 & $10 / 2$ & 13.1 & 2.6 to 65.8 \\
\hline
\end{tabular}

${ }^{\star} \mathrm{OR}=$ Mantel-Haenszel odds ratio; $\mathrm{CI}=$ confidence interval as outlined by Robins et al..$^{36}$

tAt age 25, with adjustment also for age and socioeconomic status.

$\ddagger$ Adjustment also for smoking and employment in high risk occupations.

\Adjustment also for farm work, latency requirement 15 years.

๑Adjustment also for farm work, latency requirement 20 years.

${ }^{\star \star}$ Adjustment also for work as hairdresser, latency requirement 10 years.

t+Exposure during the 5 year period preceding the diagnosis of RA.

㧊Exposure during the 5 year period preceding the onset of RA symptoms.

Assuming varying latency periods for different exposures, different latency requirements were tested, when relevant, for each determinant. Cases who were rheumatoid factor (RF) seropositive according to the medical records were analysed separately.

All determinants identified in the stratified analyses presented in this paper or in the separate publication on occupational exposures as having risk estimates of $\geqslant 1.5$ or $\leqslant 0.5$ when the number of exposed subjects was at least 10 , or when otherwise significantly different from unity, were included in a bivariate correlation matrix. All variables found to have a Pearson correlation coefficient of at least 0.500 were then included in the logistic regression analyses using the computer program SPSS (SPSS Inc, Chicago, IL, USA) to evaluate possible confounding. Men and women were analysed separately.

Unless otherwise stated, the risk estimates presented in the text result from analyses of the association between the start of exposure and the time of ARA diagnosis, without latency requirement, with both seropositive and seronegative cases included.

\section{Results}

Two hundred and eighty one cases and 507 referents participated in the study, resulting in response rates of $67 \%$ and $59 \%$, respectively. The mean age was 62 years for the cases and 58 years for the referents, and $64 \%$ and $51 \%$, respectively, were women. Seventy nine per cent of the cases were seropositive. The mean duration of the disease in the cases at the time of entry into the study was 8 years, as was the mean time span between the dummy date of onset and entry into the study for referents. For cases the mean interval between year of onset of symptoms and year of diagnosis was less than four years.

The response rate was low and therefore the possible influence of non-response bias was evaluated. These results are presented in detail in the study on occupational determinants of importance for RA. ${ }^{22}$ In summary, the comparison revealed that non-responding women were older than the women who responded, and that all non-responders were more likely to be single and to earn less than the corresponding group of responders.

Men who were current smokers had a significantly increased occurrence of RA (exposed cases/referents $40 / 62$, odds ratio (OR) $2.2,95 \%$ confidence interval (CI) 1.1 to 4.2 , with adjustment for age and socioeconomic status). Pack years of smoking were calculated by multiplying the mean number of packs per day by the total number of years of smoking. Those with no previous use of any form of tobacco were regarded as the reference group. The results are presented in table 1 . In men an increase in risk was found with increasing number of pack years. Slightly increased risks were at first seen for non-smoking men passively exposed to smoking fumes and for men reporting previous use of tobacco for buccal application (Swedish snuff), but the risks did not remain when adjustment was made for socioeconomic status.

A non-significant increased risk of RA was seen in both men and women who consumed at least $750 \mathrm{ml}$ of alcohol per drinking session at the age of 25 compared with total abstainers. With adjustment also for smoking and socioeconomic status, the ORs decreased towards unity (data not shown).

When men and women were analysed together with adjustment for age and sex, atopic allergy was less common amongst cases than among referents (exposed cases/referents $32 / 81$, OR $0.6,95 \%$ CI 0.4 to 1.0 ) and this difference was almost significant. The results were similar after adjustment for smoking habits. When the cause of the allergy was examined, somewhat decreased ORs were seen for allergic reactions to pollen (exposed cases/referents 13/39, OR $0.6,95 \%$ CI 0.3 to 1.2 ) and to house dust (exposed cases/referents 3/8, OR $0.5,95 \%$ CI 0.1 to 2.0 ). The results for men and women are shown in tables 2 and 3.

Results regarding other comorbidity, previous infections and medication, as well as results concerning educational level, residential exposures, some other external factors and psychosocial stress are also shown in tables 2 and 3. Only one of the women who reported use of insulin had previously been treated with corticosteroids. Vaccinations did not influence the risk of RA (data not shown). Most of the women who reported a joint injury at least 20 years before the diagnosis of RA had their injury before the age of 20. Previous operations 
Table 3 Case-referent evaluations of comorbidity, infections, education and some environmental exposures in men (102 cases of $R A$ and 248 referents) from southeastern Sweden, 1980-95, with adjustment for age

\begin{tabular}{|c|c|c|c|}
\hline & $\begin{array}{l}\text { Exposed } \\
\text { cases/referents }\end{array}$ & $O R^{\star}$ & $95 \% C I^{\star}$ \\
\hline \multicolumn{4}{|l|}{ Weight } \\
\hline BMI 26† & $1 / 13$ & 0.1 & 0.0 to 1.0 \\
\hline \multicolumn{4}{|l|}{ Comorbidity } \\
\hline Asthma & $3 / 9$ & 0.6 & 0.2 to 2.4 \\
\hline Allergy & $5 / 32$ & 0.4 & 0.2 to 1.1 \\
\hline Eczema & $5 / 13$ & 1.0 & 0.3 to 2.8 \\
\hline \multicolumn{4}{|l|}{ Medication } \\
\hline Antibiotics & $69 / 156$ & 1.6 & 0.9 to 2.8 \\
\hline \multicolumn{4}{|l|}{ Infections } \\
\hline Infected wounds $\ddagger$ & $8 / 15$ & 1.5 & 0.6 to 3.8 \\
\hline \multicolumn{4}{|l|}{ Educational levels } \\
\hline Compulsory school & $49 / 82$ & 1.0 & - \\
\hline Continuation/vocational school & $32 / 66$ & 0.9 & 0.5 to 1.7 \\
\hline Secondary/upper secondary school & $6 / 35$ & 0.6 & 0.2 to 1.7 \\
\hline University & $11 / 59$ & 0.5 & 0.2 to 1.1 \\
\hline \multicolumn{4}{|l|}{ Environmental exposures } \\
\hline Private well at birth & $67 / 105$ & 2.8 & 1.5 to 5.2 \\
\hline Mould at birth & $3 / 0$ & - & - \\
\hline Mould $\llbracket$ & $6 / 3$ & 4.6 & 1.1 to 20.2 \\
\hline Farm animals ${ }^{\star \star}$ & $45 / 60$ & 3.3 & 0.7 to 16.6 \\
\hline \multicolumn{4}{|l|}{ Psychosocial stress } \\
\hline Problems at work $+\dagger$ & $8 / 6$ & 3.8 & 1.2 to 11.5 \\
\hline Economic problems & $7 / 6$ & 3.3 & 1.0 to 10.2 \\
\hline
\end{tabular}

${ }^{\star} \mathrm{OR}=$ Mantel-Haenszel odds ratio; $\mathrm{CI}=$ confidence interval as outlined by Robins et al. ${ }^{36}$

†At age 25, with adjustment also for age and socioeconomic status.

$\ddagger$ Latency requirement 10 years.

\Adjustment also for smoking and employment in high risk occupations.

TAdjustment also for farm work, latency requirement 15 years.

$\star \star$ Adjustment also for farm work, latency requirement 20 years.

t†Exposure during the 5 year period preceding the diagnosis of RA.

\$Exposure during the 5 year period preceding the onset of RA symptoms.

Table 4 Case-referent evaluations of data on reproduction and breast feeding in women (179 cases of $R A$ and 259 referents) from southeastern Sweden, 1980-95, with adjustment for age

\begin{tabular}{|c|c|c|c|}
\hline & Exposed cases/referents & $O R^{\star}$ & $95 \% C I^{\star} 95 \%$ \\
\hline \multicolumn{4}{|l|}{ Menarche } \\
\hline Early & $20 / 28$ & 1.1 & 0.6 to 2.1 \\
\hline Normal† & $109 / 163$ & 1.0 & Reference \\
\hline Late & $35 / 33$ & 1.6 & 1.0 to 2.8 \\
\hline \multicolumn{4}{|l|}{ Menopause } \\
\hline Early & $15 / 13$ & 1.6 & 0.7 to 3.7 \\
\hline Normal & $48 / 63$ & 1.0 & Reference \\
\hline Late & $20 / 15$ & 1.6 & 0.7 to 3.4 \\
\hline \multicolumn{4}{|l|}{ Fertile period } \\
\hline Short & $23 / 13$ & 2.5 & 1.1 to 5.4 \\
\hline Normals & $43 / 60$ & 1.0 & Reference \\
\hline Long & $13 / 10$ & 1.5 & 0.6 to 3.9 \\
\hline Current $\mathrm{OC}^{\star}$ use $\|$ & $7 / 31$ & 0.3 & 0.1 to 0.8 \\
\hline Other exogenous sex hormones & $7 / 16$ & 0.5 & 0.2 to 1.2 \\
\hline Never parous & $32 / 31$ & 1.0 & Reference \\
\hline Ever parous ${ }^{\star \star}$ & $145 / 221$ & 0.5 & 0.3 to 0.9 \\
\hline \multicolumn{4}{|l|}{ First child at age (years) ${ }^{\star \star}$} \\
\hline$\leqslant 19$ & $18 / 19$ & 1.8 & 0.9 to 3.6 \\
\hline $20-29$ & $106 / 180$ & 1.0 & Reference \\
\hline$\geqslant 30$ & $21 / 22$ & 1.4 & 0.7 to 2.7 \\
\hline \multicolumn{4}{|l|}{ Breast feeding t+ } \\
\hline Never $\neq \ddagger$ & $22 / 16$ & 1.0 & Reference \\
\hline Ever & $123 / 205$ & 0.4 & 0.2 to 0.8 \\
\hline \multicolumn{4}{|l|}{ Duration (months) } \\
\hline$<5$ & $26 / 28$ & 0.4 & 0.1 to 1.1 \\
\hline $5-14$ & $66 / 108$ & 0.4 & 0.2 to 0.9 \\
\hline $15-24$ & $19 / 51$ & 0.3 & 0.1 to 0.7 \\
\hline \multirow[t]{2}{*}{$\geqslant 25$} & $12 / 18$ & 0.4 & 0.1 to 1.3 \\
\hline & $\mathrm{p}$ for trend $=0.063$ & & \\
\hline
\end{tabular}

$\bar{\star} \mathrm{OC}=$ oral contraceptive; $\mathrm{OR}=$ Mantel-Haenszel odds ratio $\mathrm{CI}=$ confidence interval as outlined by Robins et al. ${ }^{36}$

†Menarche at age 13-15.

$\ddagger$ Menopause at age $48-53$.

$§$ Fertile period of $34-40$ years.

II At time of diagnosis of RA.

ॠBefore onset of RA symptoms.

$\star \star$ Adjustment also for marital status.

††Adjustment also for marital status and socioeconomic status.

+\$Parous women having never breast fed.

and other kinds of trauma were not associated with RA (data not shown). No increase in risk was seen from exposure to pets (data not shown). Apart from the non-significant increase in the risk for RA in women exposed to solvents, no associations between $\mathrm{RA}$ and leisure time exposures to chemicals were found (data not shown).

The results on reproductive factors are shown in table 4. "Normal" age of menarche and menopause was defined from the age distributions seen in the female referents, and those with onset of menarche at age 13-15 and of menopause at age $48-53$ were considered as the reference group. When the onset of menopause was studied, those with a history of gynaecological operations (12 cases and 20 referents) were excluded from the analyses. In consideration of the length of the fertile period, those with a fertile period of 34-40 years were regarded as the reference group. There was no difference between cases and referents with regard to interrupted pregnancies (data not shown).

The logistic regression analyses did not produce any major changes in risk estimates to indicate confounding in men or women. Apart from some occupational exposures, the analyses included exposure to farm animals and private wells for men, and oral contraceptive use and some psychosocial factors for women.

\section{Discussion}

The response rate was lower than expected, and analyses were therefore made to evaluate the possible presence of a non-response bias. When age, socioeconomic status, and income were studied, there were no indications of a systematic non-response bias concerning socioeconomic factors since the observed differences between responders and non-responders seemed to be of similar magnitude in both cases and referents.

Subjects were unaware of the specific aim of the study and of their case-referent status to avoid any possible recall bias and most of the hypotheses tested are unknown to the public. As a dummy date of onset was used for referents, cases and referents were required to recall exposures over an equally long period of time. The awareness of the negative impact of tobacco and alcohol use in general may have resulted in an underestimation of the subjects' true consumption, but such a tendency of underreporting is probably equally likely in both cases and referents.

The use of prevalent cases of RA from the University Hospital in Linköping may have resulted in a selection bias. It is possible that those affected by more severe disease had died before the time of inclusion in the study, while those with less severe disease may have been referred to other health care units. Assuming an association between the analysed factors and disease severity, it is possible that those who had died represent cases exposed to risk factors and unexposed to preventive factors, while the opposite could be assumed for the less severe cases. However, even if an association between certain factors and disease severity is assumed, a possible counterbalancing loss of extreme cases can be expected to minimise the selection bias.

Several kinds of exposures, which probably have different mechanisms of action, have been 
studied, and it is reasonable to assume different latency periods for these. Varying latency requirements have therefore been tested and used when relevant.

There was an increased risk for RA in both current and previous smokers, and in men there was a dose-response relationship which further strengthens the credibility of a true cause-effect relationship. These results are in agreement with previous findings. ${ }^{12-14} 23$ The tendency for higher ORs in seropositive cases is also in agreement with previous findings of an association between smoking and RA severity. ${ }^{23}$ Smoking may also cause an increased production of RF in non-rheumatic subjects ${ }^{25}$ and the RF concentration in patients with RA has been shown to be linearly related to the number of years of smoking. ${ }^{23}$ Furthermore, the association between smoking and RA, especially seropositive RA, seems to be stronger in men than in women. ${ }^{1323}$

Education has been regarded as a socioeconomic marker and a low educational level has previously been found to be associated with an increase in severity of RA. ${ }^{26}$ However, in a recent study no association was seen between RA and a low educational level. ${ }^{13}$ In the present study an inverse relationship between educational level and RA prevailed after adjustments for smoking habits and occupation. It is possible that a higher educational level is associated with a healthier lifestyle or a different pattern of healthcare use.

A recent study $^{27}$ has shown that coffee consumption is associated with both RF seropositivity and development of RA. This is interesting because the amount of coffee consumed is likely to vary with other lifestyle factors previously found to be associated with RA such as smoking. However, questions concerning coffee consumption were not included in the present study.

Previous studies of the coexistence of atopic manifestations in patients with RA have shown an inverse relationship between the two conditions, ${ }^{6-8}$ supporting the theory of a functional dichotomy between Th1 and Th2 type responses. ${ }^{3}$ Assuming a lifelong commitment to either Th1 or Th2 type responses, a history of allergic manifestations in cases and referents was compared. The results from the present study support an inverse relationship between RA and atopic allergy, while the results concerning the presence of asthma and eczema were divergent between the sexes. It is possible that subjects have reported other than atopic conditions and Th1 mediated contact dermatitis might have been reported as atopic eczema. The question concerning atopic allergy is probably more reliable and is supported by the decreased risk of allergic reactions to pollen and house dust.

An association between Th1 dominated conditions is supported by the relationship between RA and insulin treatment in women as diabetes mellitus type 1 is considered to be a Th1 condition..$^{28}$ Autoimmune thyroiditis is also regarded as a Th 1 condition $^{29}$ and has previously been found to be associated with RA. ${ }^{5}$
However, those reporting thyroid conditions in this study may also have had other thyroid diseases.

Various infections have been suggested to contribute to the development of RA, and the association with antibiotics in men seen in this study may be regarded as an indication of previous bacterial diseases. In women there was also an unexpected negative relationship between RA and rubella, previously considered to be a possible risk factor for RA. ${ }^{30}$

The increased risks associated with the use of a private well and problems with mould indoors are new findings. Private wells are found in the countryside in Sweden, and the risk might be conveyed by contamination of chemicals used in nearby cultivations. Wells can also contain various organic degradation products, minerals, and bacteria.

The increased risk of RA associated with customer exposure to hair dyes and/or bleach prevailed after adjustment for work as a hairdresser. Hairdressers have previously been found to have an increased risk for $\mathrm{RA}^{17}$ and for lymphoma, ${ }^{31}$ a condition associated with $\mathrm{RA}^{32}$ and possibly also associated with customer use of hair dyes. ${ }^{33}$

The significantly decreased risk seen in women who have ever breast fed a child is not in accordance with the suggested association between RA and hyperprolactinaemia. ${ }^{210}$ However, such an inverse relationship has also been reported previously. ${ }^{34}$ Although previous studies have not associated treatment with non-contraceptive sex hormones with any major change in risk of $\mathrm{RA}^{35}$ our study indicates a possible beneficial effect from their use.

In conclusion, the findings support the hypothesis of a functional dichotomy between RA and atopy, which is characterised as a Th2 dominated disease, while there is a clinical correlation between RA and other Th1 dominated conditions such as diabetes mellitus. Most of the results relating to the role of reproductive factors and hormonal treatment are in agreement with existing theories on the influence of hormonal factors on the development of RA. Furthermore, the negative impact of lifestyle factors such as smoking is confirmed while higher education seems to have a protective effect. Most of the results on external factors such as physical and psychological trauma and residential exposures are hypothetical as there are no obvious explanations for these findings. It is likely that the risk factors and beneficial factors reported in this study act together with other aetiological or protective factors to facilitate or to prevent the end point of RA. Further studies are warranted to confirm this.

This study was supported financially by the Swedish Council for Work Life Research and the Östergötland County Council. The authors thank Mrs Azra Mujkic for assistance with data coordination.

1 Weyand CM, Goronzy JJ. The molecular basis of rheumatoid arthritis. J Mol Med 1997;75:772-85.

2 Wilder RL. Adrenal and gonadal steroid hormone deficiency in the pathogenesis of rheumatoid arthritis. J Rheuciency in the pathogen
matol $1996 ; S 44: 10-2$.

3 Miossec P, van den Berg W. Th1/Th2 cytokine balance in arthritis. Arthritis Rheum 1997;40:2105-15. 
4 Muraille E, Leo O. Revisiting the Th1/Th2 paradigm. Scand J Immunol 1998;47:1-9.

5 Silman AJ, Ollier WER, Bubel MA. Autoimmune thyroid disease and thyroid autoantibodies in rheumatoid arthritis patients and their families. Br J Rheumatol 1989;28:18-21.

6 Verhoef CM, van Roon JAG, Vianen ME, BruijnzeelKoomen CAFM, Lafeber FPJG, Bijlsma JWJ. Mutual antagonism in rheumatoid arthritis and hay fever; a role for type /type 2 T cell balance. Ann Rheum Dis 1998;57:27580.

7 Allanore Y, Hilliquin P, Coste J, Renoux M, Menkès CJ. Decreased prevalence of atopy in rheumatoid arthritis. Lancet 1998;351:497.

8 O'Driscoll BR, Milburn HJ, Kemeny DM, Cochrane GM, Panayi GS. Atopy and rheumatoid arthritis. Clin Allergy 1985; 15:547-53.

9 Hochberg MC. Changes in the incidence and prevalence of rheumatoid arthritis in England and Wales, 1970-1982. Semin Arthritis Rheum 1990;19:294-302.

10 Brennan P, Ollier B, Worthington J, Hajeer A, Silman A. Are both genetic and reproductive associations with RA linked both genetic and reproductive associa

11 Holmdahl R. Female preponderance for development of arthritis in rats is influenced by both sex chromosomes and sex steroids. Scand J Immunol 1995;42:104-9.

12 Symmons DP, Bankhead CR, Harrison BJ, Brennan P, Barrett EM, Scott DG, et al. Blood transfusion, smoking, and obesity as risk factors for the development of rheumatoid arthritis: results from a primary care-based incident case-control study in Norfolk, England. Arthritis Rheum 1997;40:1955-61.

13 Uhlig T, Hagen KB, Kvien TK. Current tobacco smoking, formal education, and the risk of rheumatoid arthritis. J Rheumatol 1999;26:47-54.

14 Karlsson EW, Lee IM, Cook NR, Manson JE, Buring JE, Hennekens $\mathrm{CH}$. A retrospective cohort study of cigarette smoking and risk of rheumatoid arthritis in female health professionals. Arthritis Rheum 1999;42:910-7.

15 Voigt LF, Koepsell TD, Nelson JL, Dugowson CE, Daling JR. Smoking, obesity, alcohol consumption and the risk for JR. Smoking, obesity, alcohol consumption and the r.

16 Krause A, Kamradt T, Burmester GR. Potential infectious agents in the induction of arthritides. Curr Opin Rheumatol 1996;8:203-9.

17 Lundberg I, Alfredsson L, Plato N, Sverdrup B, Klareskog L, Kleinau S. Occupation, occupational exposure to chemicals and rheumatological disease. Scand J Rheumato 1994;23:305-10

18 Bond C, Cleland LG. Rheumatoid arthritis: are pets implicated in its etiology? Semin Arthritis Rheum 1996;25:5, 308-17.

19 Moens HB, Corstjens A, Boon C. Rheumatoid arthritis is not associated with prior tonsillectomy or appendectomy. Clin Rheumatol 1994;13:483-6.

20 Darwish MJ, Haroutune K, Armenian K. A case-control study of rheumatoid arthritis in Lebanon. Int J Epidemiol $1987 ; 16: 420-4$
21 Arnett FC, Edworthy SM, Bloch DA, McShane DJ, Fries JF, Cooper NS, et al. The American Rheumatism Associa1987 revised criteria for the classification of rheumatoid arthritis. Arthritis Rheum 1988;31:315-24.

22 Reckner Olsson Å, Skogh T, Wingren G. Occupational determinants for rheumatoid arthritis. Scand J Work Environ Health $2000 ; 26: 243-9$.

23 Wolfe F. The effect of smoking on clinical, laboratory, and radiographic status in rheumatoid arthritis. J Rheumatol 2000;27:630-7.

24 Saag KG, Cerhan JR, Kolluri S, Ohashi K, Hunninghake GW, Schwartz DA. Cigarette smoking and rheumatoid arthritis severity. Ann Rheum Dis 1997;56:463-9.

25 Jonsson T, Thorsteinsson J, Valdimarsson H. Does smoking stimulate rheumatoid factor production in non-rheumatic individuals. APMIS 1998;106:970-4.

26 Vliet Vlieland TP, Buitenhuis NA, van Zeben D, Vandenbroucke JP, Breedveld FC, Hazes JM. Sociodemographic factors and the outcome of rheumatoid arthritis in young women. Ann Rheum Dis 1994;53:803-6.

27 Heliövaara M, Aho K, Knekt P, Ompivaara O, Reunanen A, Aromaa A. Coffee consumption, rheumatoid factor, and the risk of rheumatoid arthritis. Ann Rheum Dis 2000;59: 631-5.

28 Lafaille JJ. The role of helper $\mathrm{T}$ cell subsets in autoimmune diseases. Cytokine Growth Factor Rev 1998;9:139-51.

9 De Carli M, D'Elios MM, Zancuoghi G, Romagnani S, Del Prete G. Human Th1 and Th2 cells: functional properties, regulation of development and role in autoimmunity. Autoimmunity 1994;18:301-8.

30 Zhang D, Nikari S, Vainionpää R, Luukainen R, Yli Kerttula U, Toivanen P. Detection of rubella, mumps, and measles virus genomic RNA in cells from synovial fluid and peripheral blood in

31 Miligi L, Seniori Costantini A, Crosignani P, Fontana A, Masala G, Nanni O, et al. Occupational, environmental, and life-style factors associated with the risk of hematolymphopoietic malignancies in women. Am J Ind Med 1999;36:60-9.

32 Georgescu L, Paget SA. Lymphoma in patients with rheumatoid arthritis: what is the evidence of a link with rheumatoid arthritis: what is the evidence
methotrexate? Drug Safety 1999;20:475-87.

33 Correa A, Jackson L, Mohan A, Perry H, Helzlsouer K. Use of hair dyes, hematopoietic neoplasms, and lymphomas: a literature review. II. Lymphomas and multiple myeloma. Cancer Invest 2000;18:467-79.

34 Brun JG, Nilssen S, Kvále G. Breast feeding, other reproductive factors and rheumatoid arthritis. $\mathrm{Br} \mathrm{J}$ Rheumatol 1995;34:542-6.

35 Koepsell TD, Dugowson CE, Nelson JL, Voigt LF, Daling JR. Non-contraceptive hormones and the risk of rheumatoid arthritis in menopausal women. Int J Epidemiol 1994; 23:1248-55.

36 Robins J, Greenland S, Breslow NE. A general estimator for the variance of the Mantel-Haenszel odds ratio. Am J Epidemiol 1986;124:719-23. 


\section{MATTERS ARISING}

\section{Heavy cigarette smoking and RA}

Hutchinson et al concluded that prolonged heavy cigarette smoking, but not smoking itself, is strongly associated with rheumatoid arthritis (RA), particularly in patients without a positive family history. ${ }^{1}$ The authors proposed that increased rheumatoid factor (RF) production resulting from heavy smoking exposures explains, in part, the relation of increasing cumulative pack years smoked and the greater association with RA. ${ }^{1}$

No data were presented in that study on the extent of smoking and RF positivity or its titres. ${ }^{1}$ The proposal ${ }^{1}$ would be strengthened if heavy smoking were associated with RF, either when clinical disease began or when patients were studied at hospital rheumatology clinics. Others have proposed that tobacco smoke exposure triggers RF production, thereby contributing to the onset of RA. ${ }^{23}$ However, no significant association was seen between current smoking and $\operatorname{IgM}$ $\mathrm{RF}$ positivity in the earlier multicase family study, ${ }^{2}$ either among 41 patients with RA or their non-rheumatoid relatives-168 blood and 36 non-blood relatives. ${ }^{4}$

Although heavy cigarette smoking may be associated with RF during clinical disease, it is still relevant to determine whether it is associated with RA, either in the presence or absence of RF positivity. A further question remains as to the sequence of occurrences. Does heavy smoking first induce RF production, which later contributes to RA $?^{1-3}$ Alternatively, might RA be induced first and RF produced later? Prospective, rather than cross sectional, studies are needed to answer these questions. Prospective data suggest that reported smoking of 30 or more cigarettes daily (CS 30+/day) predisposes to RA risk independently from RF positivity or positive family history. ${ }^{56}$

These complex relationships were investigated in a case-control study nested within a community based cohort ( $\mathrm{n}=21061$ adults $)$ enrolled in 1974. For each of the 18 male and 36 female unrelated incident patients who satisfied American College of Rheumatology criteria for RA, identified in 1994, four controls from the entry cohort were matched for age, sex, and race (all white subjects). ${ }^{56}$ Table 1 shows the number of patients before they developed RA and their respective controls who reported heavy cigarette smoking (CS 30+/day) at baseline. Heavy smoking was not associated with pre-RA RF+ status, but was associated significantly $(p=0.001)$ with patients who were RF- at baseline. The highest observed odds ratio (OR) was in 15 sets in which the patient was RF- at baseline and continued to be RF- after active disease developed (OR 21.5, 95\% CI 1.9 to 122.5 , $\mathrm{p}=0.005)$. The ORs were similar for sets in which the patients had positive or negative FDR status, but was significant $(\mathrm{p}=0.012)$ only in the larger FDR- subset (table 1).

The hypothesis that cigarette smoking contributes to RA partly by RF production ${ }^{1-3}$ is attractive. However, critical substantiation in prospective and cross sectional studies is currently lacking. Available prospective data (table 1$)^{56}$ suggest that alternative mechanisms may be more likely. For example, long term cigarette smoking causes general vascular endothelial damage, ${ }^{7}$ and smoking is significantly associated with vasculitis in active RA. ${ }^{8}{ }^{9}$ Heavy smoking was proposed ${ }^{4}$ to contribute to RA risk through its endothelial and microvascular effects, perhaps through nitric oxide pathways, ${ }^{10}$ rather than by RF production primarily. ${ }^{1-3}$

Whether or not heavy smoking differentially associates with RA depending upon family history of disease ${ }^{1}$ is as complex as the dilemmas of RF contributions to onset (table 1). Our FDR+ female patients had a significantly $(p<0.001)$ younger mean age at clinical onset ( 45.6 years) than their counterparts (57.1 years). Might such earlier onset of RA among patients with a positive family history, as also noted by Hutchinson et al, ${ }^{1}$ have influenced their behaviour to lower cumulative exposures to cigarette smoking compared with their counterparts?

A T MASI

J C ALDAG

Department of Medicine,

University of Illinois College of Medicine at

Peoria,

Table 1 Numbers of pre-RA cases and matched controls reporting heavy cigarette smoking (CS $30+/$ day) at baseline by relevant categories and odds ratios (ORs) with $95 \%$ confidence intervals (95\% CIs) for developing ACR+ rheumatoid arthritis

\begin{tabular}{|c|c|c|c|c|c|c|}
\hline \multirow[b]{2}{*}{ Categories } & \multicolumn{2}{|c|}{ Pre- $R A$ cases } & \multicolumn{2}{|c|}{$\begin{array}{l}\text { Respective matched } \\
\text { controls }\end{array}$} & \multirow[b]{2}{*}{$O R$} & \multirow[b]{2}{*}{$95 \% C I$} \\
\hline & Number & $\begin{array}{l}\text { CS } 30+/ d a y \\
(\%)\end{array}$ & Number & $\begin{array}{l}\text { CS } 30+/ d a y \\
(\%)\end{array}$ & & \\
\hline Total subjects & 54 & $13(24)$ & 216 & $19(9)$ & 3.3 & 1.4 to 7.7 \\
\hline Men & 18 & $8(44)$ & 72 & $14(19)$ & 3.3 & 1.0 to 11.4 \\
\hline Women & 36 & $5(14)$ & 144 & $5(3)$ & 4.5 & 1.0 to 19.4 \\
\hline $\mathrm{FDR}+\star$ & 11 & $5(45)$ & 44 & $9(20)$ & 3.2 & 0.7 to 16.3 \\
\hline FDR- & 43 & $8(19)$ & 172 & $10(6)$ & 3.7 & 1.2 to 11.2 \\
\hline Pre-RA RF+ & 12 & $2(17) \sqrt{9}$ & 48 & $7(15) \S$ & 1.2 & 0.2 to 7.9 \\
\hline Pre-RA RF- & 42 & $11(26)$ & 168 & $12(7)$ & 4.6 & 1.5 to 10.2 \\
\hline Entry and post-RA RF- & 15 & $4(27)$ & 60 & $1(2)$ & 21.5 & 1.9 to 122.5 \\
\hline Conversion of pre-RA RF- to $\mathrm{RF}+\dagger$ & 27 & $7(26)$ & 108 & $7(6)$ & 5.1 & 1.4 to 18.5 \\
\hline FDR- and pre-RA RF- & 33 & $7(21)$ & 132 & $5(4)$ & 6.8 & 1.8 to 27.4 \\
\hline Mild course of RA $\ddagger$ & 19 & $8(42)$ & 76 & $11(14)$ & 4.3 & 1.2 to 15.1 \\
\hline Non-mild course of RA $\ddagger$ & 35 & $5(14)$ & 140 & $8(6)$ & 2.8 & 0.7 to 10.2 \\
\hline
\end{tabular}

${ }^{\star} \mathrm{FDR}+$ is a positive history of RA in a first degree relative as determined for patients in 1997, and reported in $6 / 18(33 \%)$ male patients and $5 / 36(14 \%)$ female patients

†Conversion of RF- at baseline to RF+ after clinical onset of RA.

¥Course of RA over 3-20 (median 11) years of clinical disease was determined by the patients' rheumatologist according to predefined criteria.

$\S$ No association of CS $30+/$ day with pre-RA RF+ $(p=0.99)$.
Illinois, USA

R L MALAMET

Ostoeporosis and Clinical Trials Centre,

Hagerstown, Maryland, USA

Correspondence to: Professor A T Masi, Department of Medicine, University of Illinois College of Medicine at Peoria, One Illini Drive, Box 1649, 61656, USA

1 Hutchinson D, Shepstone L, Moots R, Lear JT, Lynch MP. Heavy cigarette smoking is strongly associated with rheumatoid arthritis (RA), particularly in patients without a family history of RA. Ann Rheum Dis 2001;60:223-7.

2 McDonagh JE, Walker DJ. Smoking with rheumatoid arthritis-observations from a multicase family study: comment on the article by case family study: comment on the article by 594 .

3 Uhlig T, Hagen KB, Kvien TK. Current Uhlig T, Hagen KB, Kvien TK. Current tobacco smoking, formal education, and the
risk of rheumatoid arthritis. J. Rheumatol 1999;26:47-54

4 Masi AT, Fecht T, Aldag JC, Malamet RL, Hazes. JMW. Smoking and rheumatoid arthritis: comment on the letter by McDonagh and Walker [letter]. Arthritis Rheum 1998;41: $184-5$.

5 Masi AT, Aldag JC, Fecht T, Teodorescu M, Sipe JD, Agopian MS, et al. Rheumatoid factor positivity $(\mathrm{RF}+)$ and current cigarette smoking (CSS + ) of $30+$ daily are independent, longterm predictors of RA [abstract]. Arthritis Rheum 1997;40(suppl):S312.

6 Masi AT, Aldag JC, Chatterton RT, Teodorescu $\mathrm{M}$, Malamet RL, Comstock GW, et al.
Independent risk markers (RMs) for RA onset in males include rheumatoid arthritis (RA) in a in males include rheumatoid arthritis (RA) in a first degree relative (FDR+), rheumatoid factor
$(\mathrm{RF}+)$, combined low serum cortisol and testosterone (low C\&T), and heavy cigarette testosterone (low C\&T), and heavy cigarette
smoking (CS30+/d) [abstract]. Arthritis

7 McVeigh GE, Lemay L, Morgan D, Cohn JN. Effects of long-term cigarette smoking on endothelium-dependent responses in humans. Am J Cardiol 1996;78:668-72.

8 Struthers GR, Scott DL, Delamere JP, Sheppeard $\mathrm{H}$, Kitt $M$. Smoking and rheumatoid vasculitis. Rheumatol Int 1981;1:145-6.

9 Voskuyl AE, Zwinderman AH, Breedveld FC, Hazes JMW. Smoking and the risk of vasculitis in rheumatoid arthritis [abstract]. Br J Rheumatol 1997;36(suppl 1):164.

10 Farrell AJ, Blake DR. Nitric oxide. Ann Rheum Dis 1996;55:7-20.

\section{Authors' reply}

We read the letter of Masi et al with interest and are pleased to have an opportunity to discuss the questions they have raised. Our study group was derived from an area of northwest England made up principally of people in a lower socioeconomic class, in contrast with other UK studies. ${ }^{1}$ Although we did not record the presence of rheumatoid factor (RF) in our patients for the purpose of this study, seropositivity in our RA patient group was high, approximately $80-90 \%$. This is comparable with Glasgow, an area in Scotland with a similarly high level of social deprivation, where $96 \%$ of randomly selected patients with RA were found to be seropositive. ${ }^{2}$ We therefore decided to compare the smoking history of familial and sporadic patients with RA rather than compare seropositive and seronegative patients.

Published reports almost uniformly suggest that cigarette smoking is associated with seropositive rather than seronegative RA. Cigarette smoking is associated with the development of seropositivity in healthy subjects $^{34}$ and, furthermore, there is a dose related phenomenon for the development of seropositive RA. ${ }^{5}$ It has also been established that the development of seropositive RA is greatly increased in healthy subjects who are persistently seropositive. ${ }^{6}$ Wolfe noted a significant trend in patients with RA of 
increasing RF titre with pack years smoked.? Yet although the development of rheumatoid joint erosions, nodules, and disability was significantly increased by cigarette smoking, he found that this was independent of RF production.

We suspect that cigarette smoking and RF are strongly interlinked, but other mechanisms, as suggested by Masi, may also be at work. For example, cigarette smoke contains numerous oxidising agents that can inactivate $\alpha_{1}$-proteinase inhibitor $\left(\alpha_{1}-\mathrm{PI}\right),{ }^{8}$ the natural inhibitor of neutrophil elastase (NE), a serine proteinase that can degrade articular cartilage. ${ }^{9}$ Cigarette smoke can also prime neutrophils to degranulate and discharge NE, ${ }^{10}$ activate macrophages to produce matrix metalloproteinases, ${ }^{11}$ up regulate production of interleukin $1 \beta$ and interleukin $8^{12}$ and down regulate interleukin 1 receptor antagonist, ${ }^{13}$ and interleukin $10 .{ }^{14}$ Furthermore, cigarette smoking induces disease processes in a specific dose dependent fashion (independent of current smoking status), such as pulmonary emphysema, in which there is increased neutrophil priming, increased oxidised $\alpha_{1}$-PI and $\alpha_{1}$-PI-NE complexes (indicative of increased NE activity). ${ }^{8}$ Therefore a heavy smoker may have an otherwise benign short lived inflammatory arthritis modified by the mechanisms outlined above and develop RA.

Whether RA increases or decreases cigarette consumption remains uncertain. Our controls had a pack year total estimated at entry to the study and not at the time of their disease onset. We are, however, unaware of any data to suggest that RA increases cigarette consumption. Indeed, a study by Harrison et al observed that $18 \%$ of all smokers with polyarthritis stopped smoking within three years of disease onset as opposed to $<1 \%$ of non-smoking patients who started smoking during this period. ${ }^{15}$

Other important questions remain unanswered. For example, does increased cumulative cigarette consumption increase RA susceptibility independently of RF production? (Data presented here by Masi et al only consider cigarette consumption at one time point.) If so, do these subjects have an increased prevalence of circulating levels of $\alpha_{1}$-PI-NE complexes, high levels of oxidised and inactivated $\alpha_{1}$-PI complexes, and therefore pulmonary emphysema?

We welcome the heightened interest in the relationship between smoking and RA and look forward to the establishment of new studies designed to answer some of the interesting questions raised by recent studies.

D HUTCHINSON $\mathrm{R}$ MOOTS

Rheumatology Department, University Hospital, Aintree, Liverpool L9 7AL, UK

1 Hutchinson D, Moots RJ. Rheumatoid arthritis, poverty and smoking. Ann Rheum Dis 2000;59:396-7.

2 McEntegart A, Capell HA, Creran D, Rumley A, Woodward M, Lowe GD. Cardiovascula risk factors, including thrombotic variables, in a population with rheumatoid arthritis. Rheumatology (Oxford) 2001;40:640-4.

3 Tuomi T, Heliovaara M, Palosuo T, Aho K. Smoking, lung function, and rheumatoid factors. Ann Rheum Dis 1990;49:753-6.

4 Jonsson $\mathrm{T}$, Thorsteinsson J, Valdimarsson $\mathrm{H}$. Does smoking stimulate rheumatoid factor
production in non-rheumatic individuals? production in non-rhe
APMIS 1998;106:970-4.

5 Heliovaara $\mathrm{M}$, Aho $\mathrm{K}$, Knekt $\mathrm{P}$, Impivaara $\mathrm{O}$, Reunanen A, Aromaa A. Coffee consumption, rheumatoid factor, and the risk of rheumatoid arthritis. Ann Rheum Dis 2000;59:631-5.
6 N Halldorsdottir HD, Jonsson T, Thorsteinsson $\mathrm{J}$, Valdimarsson $\mathrm{H}$. A prospective study on the incidence of rheumatoid arthritis among people with persistent increase of rheumatoid factor Ann Rheum Dis 2000;59:149-51.

7 Wolfe $\mathrm{F}$. The effect of smoking on clinical, laboarthritis. J Rheumatol 2000;27:630-7.

8 Evans MD, Pryor WA. Cigarette smoking, emphysema, and damage to alpha 1-proteinase inhibitor. Am J Physiol 1994;266(part 1): L593-611.

9 Moore AR, Appelboam A, Kawabata K, Da Silva JA, D'Cruz D, Gowland G, et al. Destruction of articular cartilage by alpha 2 macroglobulin elastase complexes: role in rheumatoid arthritis. Ann Rheum Dis 1999;58:109-13.

10 Anderson R, Theron AJ, Richards GA, Myer MS, van Rensburg AJ. Passive smoking by humans sensitizes circulating neutrophils. Am Rev Respir Dis 1991;144(part 1):570-4.

11 Selman M, Montano M, Ramos C, Vanda B, Becerril C, Delgado J, et al. Tobacco smokeinduced lung emphysema in guinea pigs is associated with increased interstitial collagenase. Am J Physiol 1996;271(part 1):L734gen 43.

12 Kuschner WG, D'Alessandro A, Wong H, Blanc PD. Dose-dependent cigarette smoking-related inflammatory responses in healthy adults. Eur Respir J 1996;9:1989-94

13 Hofbauer LC, Muhlberg T, Konig A, Heufelder G, Schworm HD, Heufelder AE. Soluble interleukin-1 receptor antagonist serum levels in smokers and nonsmokers with Graves' ophthalmopathy undergoing orbital radiotherapy. J Clin Endocrinol Metab 1997;82:2244-7.

14 Takanashi S, Hasegawa Y, Kanehira Y, Yamamoto K, Fujimoto K, Satoh K, et al. Interleukin-10 level in sputum is reduced in Interleukin-10 level in sputum is reduced in
bronchial asthma, COPD and in smokers. Eur bronchial asthma, COPD
Respir J.1999;14:309-14.

15 Harrison BJ, Silman AJ, Wiles NJ, Scott DG, Symmons DP. The association of cigarette smoking with disease outcome in patients with early inflammatory polyarthritis. Arthritis Rheum 2001;44:323-30.

\section{Rheumatoid arthritis associated with ulcerative colitis}

I was interested to read the letter on "Rheumatoid arthritis associated with ulcerative colitis" by Boyer et al published recently in the Annals, ${ }^{1}$ and would like to make the following comments. Studies in patients with established Crohn's disease (CD) have generally supported the predominance of Th1 responses. ${ }^{2}{ }^{3}$ In ulcerative colitis, although enhanced humoral immunity has been described, evidence for classical Th2 predominance remains to be demonstrated. On the other hand, it has been shown that interleukin 15 is overexpressed in the inflamed mucosa of patients with inflammatory bowel disease at the level of macrophages.. ${ }^{4}$ Similar findings have been reported in patients with rheumatoid arthritis (RA). ${ }^{5}$

As shown in this case, it is sometimes quite difficult to distinguish by clinical manifestations alone between two diseases which start almost at the same time. However, the presence of a positive rheumatoid factor and DR1 genotype are arguments for RA. The existence of polymorphisms affecting other genes may take place in such type of arthritis. ${ }^{6}$

Results obtained with anti-tumour necrosis factor monoclonal antibody to prevent mucosal inflammation in $\mathrm{CD},{ }^{7}$ suggest that such an approach may also be of interest in this unusual situation.

J A MOSQUERA-MARTINEZ Rua ILLA de Tambo-96, Poio-Pontevedra, 36005 Spain andrea@dragonet.es
1 Boyer F, Fontanges E, Miossec P. Rheumatoid arthritis associated with ulcerative colitis: a case with severe flare of both diseases after delivery. Ann Rheum Dis 2001;60:901.

2 Plevy SE, Landers CJ, Prehn J, Carramanzana NM, Deem RL, Shealy D, et al. A role for TNF-alpha and mucosal T helper-1 cytokines in the pathogenesis of Crohn's disease. J Immunol 1997;159:6276-82.

3 Fuss IJ, Neurath M, Boirivant M, Klein JS, de la Motte C, Strong SA, et al. Disparate CD4+ Motte C, Strong SA, et al. Disparate CD4+
lamina propria (LP) lymphokine secretion profiles in IBD. Crohn's disease LP cells manifest increased secretion of IFN-gamma, whereas UC LP cells manifest increased secretion of IL-5. J Immunol 1996;157:1261-70.

4 Liu Z, Geboes K, Colpaert S, D'Haens G, Rutgeerts P, Ceuppens JL. IL-15 is highly expressed in IBD and regulates local $\mathrm{T}$ celldependent cytokine production. J Immunol 2000;3608-15.

5 McInnes IB, Al-Mughales J, Field M, Leung BP, Huang F, Dixon R, et al. The role of IL-15 in T-cell migration and activation in rheumatoid arthritis. Nat Med 1996;2:175

6 Orchard TR, Thiyagaraja S, Welsh KI, Wordsworth BP, Gaston JSH, Jewell DP. Clinical phenotype is related to HLA genotype in the peripheral arthropathies of IBD. Gastroenterology 2000;118:274-8.

7 Targan SR, Hanauer SB, van Deventer SJH, Mayer L, Present DH, Braakman T, et al. A short-term study of chimeric monoclonal antibody cA2 to TNF- $\alpha$ for Crohn's disease. N Engl J Med 1997;337:1029.

\section{Authors' reply}

We thank Dr Mosquera-Martinez for his letter and are happy that our report has stimulated active discussion and suggestions. ${ }^{1}$ Indeed, control of disease was difficult even when combining methotrexate $15 \mathrm{mg} /$ week IM, salazopyrine $3 \mathrm{~g} /$ day, and prednisone 10 $\mathrm{mg} /$ day. The patient still had active arthritis affecting wrists and hands with an erythrocyte sedimentation rate (ESR) of $47 \mathrm{~mm} / 1 \mathrm{st}$ h. Furthermore, she also had active colitis, and current treatment prevented surgery for colon anastomosis.

Accordingly, infliximab was started following the now classical rheumatoid arthritis protocol. ${ }^{2}$ Seven months later, steroids could be stopped. Surgery for permanent colon anastomosis could then be performed with success and with no healing delays. When last seen in July 2001, she showed major improvement, with no pain at night and no morning stiffness. She had gained weight and had no sign of active colitis. The ESR was $26 \mathrm{~mm} / 1 \mathrm{st}$ $\mathrm{h}$ and $\mathrm{C}$ reactive protein $<4 \mathrm{mg} / \mathrm{l}$.

Such follow up extends the concept of common mechanisms between rheumatoid arthritis and ulcerative colitis. Both diseases appear to depend, at least in part, on the contribution of tumour necrosis factor $\alpha$.

$$
\begin{array}{r}
\text { F BOYER } \\
\text { E FONTANGES } \\
\text { P MIOSSEC } \\
\text { Departments of Immunology and } \\
\text { Rheumatology, } \\
\text { Hôpital Edouard Herriot, } \\
\text { Lyon, France }
\end{array}
$$

1 Boyer F, Fontanges E, Miossec P. Rheumatoid arthritis associated with ulcerative colitis: a case with severe flare of both diseases after delivery. Ann Rheum Dis 2001;60:901

2 Maini R, St Clair EW, Breedveld F, Furst D, Kalden J, Weisman $M$, et al. Infliximab (chimeric anti-tumour necrosis factor alpha monoclonal antibody) versus placebo in rheumatoid arthritis patients receiving concomitant methotrexate: a randomised phase III trial. ATTRACT Study Group. Lancet 1999;354: 1932-9. 


\section{Intramuscular methotrexate in inflammatory rheumatic disease}

We read with great interest the recent letter entitled "Is parenteral methotrexate worth trying?" by Osman and Mulherin. ${ }^{1}$ There has been an increased use of intramuscular methotrexate (IM-MTX) in our department in the past two years, leading to an increased workload in the nurse-led monitoring clinics and in the cost. This has prompted us to review the clinical utility of switching patients to IM-MTX. In addition, we have recorded patients' experiences, focusing chiefly on patient satisfaction, with this treatment.

Medical case notes of 31 patients who had started treatment with IM-MTX, identified from our database, were examined. The clinical diagnosis, previous drug treatment, reason for changing to IM-MTX, efficacy, and side effects were noted. In addition, the patients were asked to complete a questionnaire, looking at patient satisfaction and preferred venue for injections (monitoring clinic or local doctor's surgery/home).

Our patient cohort was made up of 24 patients with rheumatoid arthritis, four with seronegative spondyloarthritis, two with systemic lupus erythematosus, and one with undifferentiated connective tissue disease. Most patients had been receiving a previous disease modifying antirheumatic drug (DMARD), including 24 patients taking oral MTX. Reasons for changing to IM-MTX treatment were as follows: side effects in 11 patients, loss of efficacy in 12, and poor oral compliance in eight. The median starting and maintenance doses were $10 \mathrm{mg}$ weekly (range 5-17.5) and $15 \mathrm{mg}$ weekly (range 10-17.5), respectively. During the study, five patients discontinued IM-MTX: two because of side effects, one developed multiple nodulosis, one did not attend for follow up, and one died from an unrelated cause. Median duration of treatment in the remaining 26 patients was 10 months (range 1-20). Significant improvement in disease activity, as measured by erythrocyte sedimentation rate and $C$ reactive protein, was seen after three months $(\mathrm{p}<0.01)$, with improvement maintained after nine months $(\mathrm{p}<0.01)$ of IM-MTX treatment. Twenty four of the 26 current patients completed the questionnaire. On a satisfaction scale of $1-5$, the average rating was 4.2 , indicating that patients were either very or extremely satisfied with their IMMTX treatment. Fourteen patients preferred their injections in the monitoring clinic, five patients preferred their local doctor's surgery, and five patients expressed no preferences. Only three patients stated that weekly clinic visits were inconvenient.

In conclusion, we found that IM-MTX was effective and well tolerated. In addition, our observations further support the switch to parenteral MTX in those patients previously intolerant or who have failed to respond to oral MTX. ${ }^{2}$ Surprisingly, most patients preferred to have their injections in the monitoring clinic. The reason for this is not clear. Possibly, the patients felt more confident if cytotoxic drugs were given by a trained healthcare professional, although a previous study by Arthur et al has found that self injection of DMARDs is safe, convenient, and time and cost saving to the patient. ${ }^{3}$ We are currently comparing the administration of parenteral MTX in the monitoring clinic with self administration in the community. ReMTX in rheumatic diseases is likely to expand and the cost and resource implications of continuing with this treatment need to be discussed.

$$
\begin{array}{r}
\text { G BURBAGE } \\
\text { R GUPTA } \\
\text { K LIM } \\
\text { Department of Rheumatology, } \\
\text { Kings Mill Centre, } \\
\text { Sherwood Forest Hospitals NHS Trust, } \\
\text { Mansfield Road, } \\
\text { Notts NG17 4fL, UK }
\end{array}
$$

Correspondence to: Dr K Lim

1 Osman A, Mulherin D. Is parenteral methotrexate worth trying? Ann Rheum Dis 2001;60:432.

2 Hamilton RA, Kremer JM. Why intramuscular methotrexate may be more efficacious than oral dosing in patients with reumacious than oral J Rheumatol. 1997;36:86-90.

3 Arthur AB, Klinkhoff AV, Teufel A. Safety of self-injection of gold and methotrexate. J Rheumatol 1999;26:302-5.

\section{Author's reply}

It is gratifying that Drs Burbage, Gupta, and Lim have also demonstrated efficacy and high levels of patient satisfaction associated with parenteral methotrexate in their study. There remains a surprising dearth of reported information about this useful and widely prescribed development in rheumatology practice. Because of the burgeoning number of patients being treated in this way, it is creating increasing logistical difficulties. It represents an unlicensed use of this drug, which can cause anxiety among less experienced practitioners. Issues related to the appropriate disposal of the residual cytotoxic waste have also caused considerable difficulties. Although weekly oral methotrexate, prescribed and monitored within primary care, is an extremely cheap and effective treatment for rheumatoid arthritis, this is certainly not the case for parenteral methotrexate if it is necessary for it to be prescribed and administered in a costly secondary care setting. As primary care buckles under increasing demands on its resources, cost and logistical issues, rather than issues of efficacy, may curtail the deserved role of parenteral methotrexate in current and future rheumatology practice.

D MULHERIN Cannock Chase Hospital, Brunswick Road, Cannock WS11 2XY, UK gardless of the outcome, the role of parenteral

\section{LETTERS TO THE EDITOR}

\section{Epidemiology of vasculitis in Europe}

We recently compared the annual incidence of primary systemic vasculitis (PSV) in two different regions of Europe (Norwich, UK (latitude $52^{\circ} \mathrm{N}$ ) and Lugo, Spain (latitude $\left.\left.43^{\circ} \mathrm{N}\right)\right){ }^{1} \quad$ Wegener's granulomatosis (WG) was more common in Norwich (10.6/million) than in Spain (4.9/million), though the overall incidence of PSV was similar. This supports the idea that environmental factors may be important in the aetiopathogenesis of PSV. To extend our observations we have now studied the incidence of PSV in northern Europe (Tromsø, Norway (latitude $70^{\circ} \mathrm{N}$ )). The same methodology was used as in the previous study. ${ }^{1}$ All new patients presenting with PSV between 1 January 1988 and 31 December 1998 were identified in the three centres. WG, Churg-Strauss syndrome (CSS), and polyarteritis nodosa (PAN) were classified by the American College of Rheumatology (1990) criteria, $^{2-4}$ and microscopic polyangiitis (MPA) and classical PAN by the Chapel Hill consensus definition. ${ }^{5}$ Incidence figures were calculated using the Poisson distribution for the observed number of cases.

Table 1 shows the results obtained. The overall incidence and pattern of vasculitis was similar in the three regions, but there were some differences. MPA was less common in Tromsø than in the other two regions, and there was a trend for WG to be more common in the north. CSS was more common in Norwich than in the other two regions. In all areas and all disease categories the incidence was greater in men than women and showed a peak incidence at age 65-74. Overall, WG is the most common type of PSV and classical PAN the rarest.

These results support the notion suggested by doctors interested in vasculitis that there are geographical differences in the incidence of WG, MPA, and CSS, and, in particular, there is an inverse relation between the incidence of WG and MPA. In clinical prac-

\begin{tabular}{|c|c|c|c|c|c|c|c|}
\hline & \multirow{2}{*}{$\begin{array}{l}\text { Criterial } \\
\text { definition }\end{array}$} & \multicolumn{2}{|c|}{ Tromsø } & \multicolumn{2}{|c|}{ Norwich } & \multicolumn{2}{|c|}{ Lugo } \\
\hline & & $n$ & Imillion (95\% CI) & $n$ & Imillion (95\% CI) & $n$ & Imillion (95\% CI) \\
\hline $\mathrm{WG}^{\star}$ & ACR† & 43 & $10.5(7.6$ to 14.2$)$ & 48 & $10.6(7.8$ to 14.0$)$ & 11 & $4.9(2.4$ to 8.8$)$ \\
\hline $\mathrm{CSS}^{\star}$ & ACR & 2 & $0.5(0.06$ to 1.8$)$ & 14 & $3.1(1.7$ to 5.2$)$ & 2 & $0.9(0.1$ to 3.2$)$ \\
\hline $\mathrm{MPA}^{\star}$ & $\mathrm{CHCC}+$ & 11 & $2.7(1.3$ to 4.8$)$ & 38 & $8.4(5.9$ to 11.5$)$ & 26 & $11.6(7.6$ to 17.0$)$ \\
\hline $\mathrm{PAN}^{\star}$ & ACR & 18 & $4.4(2.6$ to 7.0$)$ & 44 & $9.7(7.0$ to 13.0$)$ & 14 & $6.2(3.4$ to 10.5$)$ \\
\hline PAN & $\mathrm{CHCC}$ & 2 & $0.5(0.06$ to 1.8$)$ & 0 & $0.0(0.0$ to 0.8$)$ & 2 & $0.9(0.1$ to 3.2$)$ \\
\hline Total & & 56 & 13.7 (10.3 to 17.8$)$ & 86 & $18.9(15.1$ to 23.4$)$ & 41 & 18.3 (13.1 to 24.8 ) \\
\hline
\end{tabular}
tice MPA and WG can be difficult to distinguish. Possibly, despite our best attempts to harmonise the application of classification criteria/definitions, there were still differences in approach. The reason for the apparent excess of CSS in Norwich is unclear

Table 1 Annual incidence of primary systemic vasculitis in three regions of Europe

$\mathrm{n}=$ number of patients fulfilling each criteria in each centre, 18 Tromsø patients, 24 Norwich patients, and 12 Lugo patients fulfilled more than one set of classification criteria. Total represents the number of patients seen in each centre.

*WG $=$ Wegener's granulomatosis; CSS = Churg-Strauss syndrome; MPA = microscopic polyangiitis; PAN $=$ polyarteritis nodosa.

†ACR = American College of Rheumatology; CHCC = Chapel Hill Consensus definition. 
but might reflect local environmental factors. The aetiopathogenesis of PSV is unknown, but both genetic and environmental factors are likely to be important. The clinically observed differences between MPA and WG may reflect interaction of varying trigger factors on a heterogeneous genetic background. It should therefore not be assumed that the same triggers operate in all regions of Europe.

R A WATTS

$S$ E LANE

D G I SCOTT

Department of Rheumatology, Norfolk and Norwich Hospital,

Norwich NR1 3SR, UK

W KOLDINGSNES

H NOSSENT

University of Tromsø,

Norway, N-9037

M A GONZALEZ-GAY C GARCIA-PORRUA

Rheumatology Section,

Hospital-Xeral-Calde,

Lugo, Spain

G A BENTHAM

Environmental Sciences,

University of East Anglia,

Norwich NR4 7TF, UK

1 Watts RA, Gonzalez-Gay M, Garcia-Porrua C, Lane S, Bentham G, Scott DGI. Geoepidemiology of systemic vasculitis. Ann Rheum Dis 2001;60:170-2.

2 Lightfoot RW Jr, Michel AB, Bloch DA, Hunder GG, Zvailfer NJ, McShane DJ, et al. The American College of Rheumatology 1990 criteria for the classification of polyarterit
nodosa. Arthritis Rheum 1990;33:1088-93.

nodosa. Arthritis Rheum 1990;33:1088-93.
3 Leavitt RY, Fauci AS, Bloch DA, Michel BA, Hunder GG, Arend WP, et al. The American College of Rheumatology 1990 criteria for the classification of Wegener's granulomatosis. Arthritis Rheum 1990;33:1101-7.

4 Masi AT, Hunder GG, Lie JT, Michel BA, Bloch DA, Arend WP, et al. The American College of Rheumatology 1990 criteria for the classification of Churg Strauss syndrome (allerS gic granulomatosis and angiitis). Arthritis
Rheum 1990;33:1094-100. Rheum 1990,

Jennette JC, Falk RJ, Andrassy K, Bacon PA Churg J, Gross WL, et al. Nomenclature of systemic vasculitides. Proposal of an international
consensus conference. Arthritis Rheum 1994; 37:187-92.

\section{Anti-U3 snRNP antibodies in localised scleroderma}

Localised scleroderma (LScl) is a connective tissue disorder usually limited to the skin and subcutaneous tissue, but it sometimes affects the muscle beneath the cutaneous lesions. The absence of Raynaud's phenomenon, acrosclerosis, and internal organ involvement differentiates LScl from systemic sclerosis (SSc). ${ }^{1} \mathrm{LScl}$ has been reported to be accompanied by a variety of abnormal immune reactions, such as the presence of antinuclear antibody, rheumatoid factor, anti-singlestranded DNA antibody (anti-ssDNA), and antihistone antibody. ${ }^{2-5}$

In our laboratory an indirect immunofluorescent study showed nucleolar staining in the serum samples of some patients with LScl. Although autoantibodies to nucleolar antigens have been well described in patients with SSc, ${ }^{67}$ these antibodies have not been determined in patients with LScl, and the incidence of anti-U3 snRNP antibodies has not been described previously. In this study we investigated the prevalence of anti-U3 snRNP antibodies using RNA immunoprecipitation, ${ }^{8}$ and examined the clinical and laboratory features of patients with LScl. In addition, we examined the serum samples of patients with SSc and control subjects matched for age and sex with the patients with LScl.

We found anti-U3 snRNP antibodies in $2 / 70(3 \%)$ serum samples from the patients with LScl (fig 1). One of the 28 patients (4\%) with linear scleroderma and one of the 20 patients (5\%) with morphoea had anti-U3 snRNP antibodies (table 1). This prevalence was smaller than that in patients with SSc, ${ }^{9}$ but there was no significant difference. RNA immunoprecipitation using silver staining of the RNA is not as sensitive as other methods-for example, probing with a labelled U3 snRNP probe. Possibly, some anti-U3 snRNP positive serum samples might have been missed. The three patients with SSc and with anti-U3 snRNP antibodies were diagnosed as having diffuse cutaneous SSc, and they tended to be older and have disease of longer duration than patients with LScl; the difference was not significant. In this study the titres of antinucleolar antibodies in the two patients with LScl with anti-U3 snRNP antibodies were $1 / 320$ and $1 / 640$, respectively. The titres of this antibody did not change in a follow up study. A previous study reported that $43 / 46$ patients with SSc and anti-U3 snRNP antibodies produced bright nucleolar staining with titres $>1 / 640 .^{10}$ Taken together, the titres of antinucleolar antibodies in patients with LScl were as high as those in SSc. Patients with LScl and with anti-U3 snRNP antibodies did not have sclerodactyly or nailfold bleeding. Raynaud's phenomenon did not occur at any time in the course of their disease. These results suggest that anti-U3 snRNP antibodies occur in patients with $\mathrm{LScl}$ as well as in those with SSc.

The patients with LScl and anti-U3 snRNP antibodies tended to be younger, have shorter disease duration, have fewer sclerotic

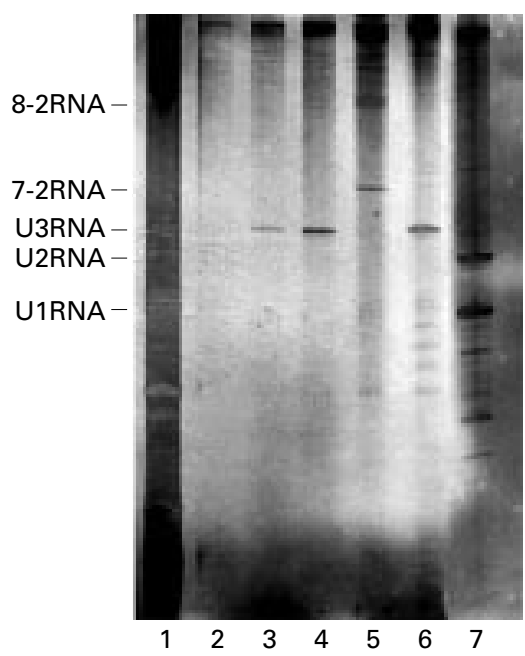

Figure 1 RNA immunoprecipitation. Urea (7 $M / 10 \%$ polyacrylamide gel electrophoresis of phenol-extracted immunoprecipitates from $\mathrm{HeLa}$ cell extracts were stained with silver. Total nucleic acids, with 7-2RNA, 8-2RNA, and the $U$ $s n R N A$ regions are indicated. Serum samples used for immunoprecipitation included: lane 1, total RNA; lane 2, healthy control serum; lanes 3-4, patients with LScl and with anti-U3 snRNP antibodies; lane 5, patient with SSc and anti-Th/To ribonucleoprotein antibodies; lane 6, patient with SSc and anti-U3 snRNP antibodies; lane 7, patient with systemic lupus erythematosus and anti-Sm antibodies.
Table 1 Frequencies of antibodies to U3 small nuclear ribonucleoprotein (snRNP), detected by immunoprecipitation, in patients with localised scleroderma (LScl), systemic sclerosis (SSc), and control subjects

\begin{tabular}{ll}
\hline & $\begin{array}{l}\text { Anti-U3 snRNP } \\
\text { antibodies (\%) }\end{array}$ \\
\hline Patients with LScl & $2 / 70(3)$ \\
GM & $0 / 22(0)$ \\
LS & $1 / 28(4)$ \\
M & $1 / 20(5)$ \\
Patients with SSc & $3 / 30(10)$ \\
Control subjects & $0 / 40(0)$
\end{tabular}

$\mathrm{LScl}=$ localised scleroderma; $\mathrm{GM}=$ generalised morphoea; LS = linear scleroderma; $M=$ morphoea; SSc $=$ systemic sclerosis.

lesions, and have fewer affected areas than those without, but there was no significant difference. We could not find any correlations with clinical manifestations, probably because of the small number of patients. In earlier investigations of systemic sclerosis, anti-U3 snRNP antibodies did not seem to have any distinctive clinical and laboratory correlation. A large group of patients with SSc was assembled and the clinical features of the patients with anti-U3 snRNP antibodies investigated; various clinical associations were reported. ${ }^{9}$ A large group of patients with LScl might similarly disclose clinical associations of patients with $\mathrm{LScl}$ with anti-U3 snRNP antibodies.

Previous studies have shown that anti-U3 snRNP antibodies rarely coexist with other autoantibodies. ${ }^{9}$ Okano et al reported that each distinctive serum antibody is associated with its own unique combination of clinical features. ${ }^{9}$ In our study antihistone antibodies or anti-ssDNA did not coexist with anti-U3 snRNP antibodies, and no other autoantibodies were detected by RNA immunoprecipitation. LScl may be a heterogeneous condition with diverse autoantibodies, and these antibodies may have a mutually exclusive status.

In conclusion, we showed for the first time that anti-U3 snRNP antibodies are found in patients with LScl by RNA immunoprecipitation. We found no correlations between clinical and laboratory manifestations in the present study. Our study suggests that the presence of anti-U3 snRNP antibodies is one of the serological abnormalities in LScl. A study of more patients may assist in showing a distinctive association between anti-U3 snRNP antibodies and the clinical and laboratory features of patients with LScl.

K YAMANE
H IHN
M KUBO
Y ASANO
N YAZAWA
K TAMAKI
Department of Dermatology,
Faculty of Medicine,
University of Tokyo, Tokyo, fapan

M KUWANA

Division of Cellular Signalling, Institute for Advanced Medical Research, Keio University School of Medicine,

Tokyo, fapan

Correspondence to: Dr H Ihn, Department of Dermatology, Faculty of Medicine, University of Tokyo, 7-3-1 Hongo, Bunkyo-ku, Tokyo 113-8655, Japan

IN-DER@h.u-tokyo.ac.jp

1 Rodnan GP. When is scleroderma not scleroderma? Bull Rheum Dis 1981;31:7-10. 
2 Takehara K, Moroi Y, Nakabayashi Y, Ishibash Y. Antinuclear antibodies in localized scleroderma. Arthritis

3 Falanga V, Medsger TA Jr, Reichlin M, Rodnan GP. Linear scleroderma: clinical spectrum, prognosis, and laboratory abnormalities. Ann Intern Med 1986;104:849-57.

4 Takehara K, Kikuchi K, Soma Y, Igarashi A, Ishibashi Y. Anti-single-strand DNA antibody and muscle involvement in localized scleroderma. Arch Dermatol 1990;126:1368-9.

5 Sato S, Ihn H, Soma Y, Igarashi A, Tamaki T, Kikuchi $\mathrm{K}$, et al. Antihistone antibodies in ocalized scleroderma. Arthritis Rheum 1993, 36:1137-41

6 Reimer G, Steen VD, Penning CA, Medsger TA $\mathrm{Jr}$, Tan EM. Correlates between autoantibodies r, Tan EM. Correlates between autoantibodies patients with systemic patients with systemic sclerosis (scier

7 Kipnis RJ, Craft J, Hardin JA. The analysis of antinuclear and antinucleolar autoantibodies of scleroderma by radioimmunoprecipitation asays. Arthritis Rheum 1990;33:1431-7.

8 Kuwana M, Kaburaki J, Mimori T, Tojo T, Homma M. Autoantibody reactive with three classes of RNA polymerases in sera from patients with systemic sclerosis. J Clin Inves 1993;91:1399-404.

9 Okano Y, Steen VD, Medsger TA Jr. Autoantibody to U3 nucleolar ribonucleoprotein (fibrillarin) in patients with systemic sclerosis. Arthritis Rheum 1992;35:95-100.

10 Reimer G, Rose KM, Scheer U, Tan EM Autoantibody to RNA polymerase I in scleroderma sera. J Clin Invest 1987;79:65-72.

\section{Telomerase activity in peripheral blood mononuclear cells from patients with SLE}

Telomerase is a reverse transcriptase that adds the telomeric sequence to the terminal of chromosomes, prevents shortening of telomere, and maintains the complete telomeric structure. ${ }^{1}$ It has been recently reported that an increase in telomerase activity is associated with the activation of lymphocytes, ${ }^{2-7}$ and, in general, much attention has been paid to the role of telomerase in immunopathology. Katayama et al reported the telomerase activity in patients with systemic lupus erythematosus (SLE). ${ }^{8}$ They analysed 17 patients with SLE, and the telomerase activity in peripheral mononuclear cells was increased to $64.7 \%$. Thus, in this study, we divided patients with SLE into treated and untreated groups, and measured the telomerase activity of peripheral mononuclear cells

Thirteen patients with SLE (1 man, 12 women) with a mean (SD) age of 30.7 (6.5) years (range 19-61) were enrolled in this study. All patients fulfilled the 1997 revised American Rheumatism Association criteria. As a control group, 10 normal volunteers, six women aged 19-41 and four men aged $30-37$, were also included in the study. After informed consent had been obtained, $10 \mathrm{ml}$ of peripheral blood was taken and heparinised. The mononuclear cell fraction was isolated from $10 \mathrm{ml}$ of heparinised peripheral blood by Ficoll-Paque (Sigma Inc, St Louis, USA) density gradient centrifugation. A sample of $1.0 \times 10^{6}$ mononuclear cells was analysed by the TRAP assay method. The TRAP assay was performed with a TRAPeze telomerase detection kit produced by the Intergen Company (Purchase, NY, USA). The level of telomerase activity was expressed by a ratio of the entire TRAP ladders to an internal control band.

Table 1 shows the telomerase activity level data and clinical data used for determining the SLE Disease Activity Index (SLEDAI). Significant differences $(p=0.006)$ were detected in the telomerase activity level between the control group, untreated SLE group, and treated SLE group by Kruskal-Wallis test with a significance level of $5 \%$. For multiple comparisons the Mann-Whitney $U$ test was used to evaluate intergroup differences after lowering the significance level using Bonferroni's technique. The $p$ value was 0.002 between the control group and untreated SLE group, 0.005 between the untreated SLE group and treated SLE group, and 0.118 between the control group and treated SLE group. Compared with other groups, telomerase activity was significantly higher in the SLE untreated group. The Spearman rank correlation test with a significance level of $5 \%$ showed a significant positive relationship between telomerase activity and SLEDAI in the SLE group with a correlation coefficient of 0.872 and $p$ value of 0.003 . The relation between telomerase activity and clinical data in SLEDAI was also analysed using the Spearman rank correlation test with a significance level of $5 \%$ in the SLE group. The correlation coefficient and $\mathrm{p}$ value were -0.614 and 0.033 between telomerase activity and white blood cell count, -0.715 and 0.013 between telomerase activity and serum complement activity, and 0.637 and 0.027 between telomerase activity and serum IgG level, respectively, with a significance level of
$5 \%$. However, the relation between telomerase activity and other clinical data was not significant in the SLE group. Telomerase activity was measured before and after treatment and changes in the activity level were analysed.

SLEDAI decreased in all patients after treatment. Wilcoxon signed rank test with a significance level of 5\% showed a significant decrease in telomerase activity $(\mathrm{p}=0.043)$ after treatment.

The treatment reduced the telomerase activity in peripheral mononuclear cells. We could not confirm whether the cause was due to the steroids or the reduction of disease activity. However, because the telomerase activity of peripheral mononuclear cells was correlated with SLEDAI, the peripheral blood telomerase activity may be useful in the evaluation of disease activity and in judging the therapeutic effects in SLE.

D KUROSAKA Y OZAWA J YASUDA

T YOKOYAMA A YAMADA Division of Rheumatology, Department of Internal Medicine, fikei University School of Medicine

M AKIYAMA Department of Paediatrics, Fikei University School of Medicine

S SAITO

Department of Molecular Immunology, Institute of DNA Medicine, Fikei University School of Medicine

N TAJIMA

Division of Diabetes and Endocrinology, Department of Internal Medicine, Fikei University School of Medicine

Correspondence to: Dr D Kurosaka, Division of Rheumatology Department of Internal Medicine Jikei University School of Medicine, 3-25-8 Nishishinbashi, Minato-ku Tokyo, 105-8461 Japan

d_kurosaka@jikei.ac.jp

1 Counter CM. The roles of telomeres and telomerase in cell life span. Mutat Res 1996;366:45-63.

2 Hiyama K, Hirai Y, Kyoizumi S, Akiyama M, Hiyama E, Piatyszek MA, et al. Activation of telomerase in human lymphocytes and hemattelomerase in human lymphocytes and hematopoietic prog $3711-15$.

Table 1 Telomerase activity and clinical laboratory parameters and SLE disease activity index (SLEDAI)

\begin{tabular}{|c|c|c|c|c|c|c|c|c|c|c|c|c|c|c|c|c|c|}
\hline $\begin{array}{l}\text { Patient } \\
\text { No }\end{array}$ & Age & Sex & $\begin{array}{l}\text { Telomerase } \\
\text { activity }\end{array}$ & $W B C$ & Lymph. & $\begin{array}{l}\text { Plt. } \\
\left(\times 10^{3}\right)\end{array}$ & $\mathrm{CH}_{50}$ & $\begin{array}{l}I C \\
(C 1 q)\end{array}$ & $d s D N A$ & $u$-prot. & $A N A$ & $\operatorname{Ig} G$ & $\operatorname{Ig} A$ & $\operatorname{Ig} M$ & $S L E D A I$ & Symptom & $\begin{array}{l}\text { Treatment } \\
\text { (prednisolone) }\end{array}$ \\
\hline \multirow[t]{2}{*}{1} & \multirow[t]{2}{*}{23} & \multirow[t]{2}{*}{$M$} & 1.96 & 2700 & 800 & 158.0 & 31.2 & 1.5 & 5 & $(-)$ & 640 & 14.69 & 3.05 & 0.53 & 10 & $2,4,5,6,8$ & None \\
\hline & & & 0.00 & 6500 & 1200 & 211.0 & 37.0 & 1.9 & 5 & $(-)$ & 1280 & - & - & - & 2 & None & $20 \mathrm{mg} /$ day \\
\hline \multirow[t]{2}{*}{2} & \multirow[t]{2}{*}{36} & \multirow[t]{2}{*}{$\mathrm{F}$} & 0.76 & 2900 & 900 & 48.0 & 23.6 & 9.3 & 165 & $(1+)$ & 1280 & 12.82 & 1.68 & 0.65 & 12 & $2,4,8$ & None \\
\hline & & & 0.00 & 5800 & 1700 & 243.0 & 29.2 & - & 72 & $(-)$ & - & - & - & - & 2 & None & $30 \mathrm{mg} /$ day \\
\hline \multirow[t]{2}{*}{3} & \multirow[t]{2}{*}{28} & \multirow[t]{2}{*}{$\mathrm{F}$} & 0.82 & 3700 & 1000 & 226.0 & 31.6 & 1.5 & 77 & $( \pm)$ & 640 & 18.98 & 3.89 & 1.98 & 10 & $2,5,8$ & None \\
\hline & & & 0.78 & 8000 & 700 & 253.0 & 28.1 & 1.5 & 32 & $( \pm)$ & 1280 & - & - & - & 2 & None & $20 \mathrm{mg} /$ day \\
\hline \multirow[t]{2}{*}{4} & \multirow[t]{2}{*}{61} & \multirow[t]{2}{*}{$\mathrm{F}$} & 0.47 & 3600 & 400 & 201.0 & 15.0 & 34.5 & 83 & $( \pm)$ & 5120 & 31.37 & 3.44 & 0.76 & 16 & $2,3,4,5,8$ & None \\
\hline & & & 0.29 & 5800 & 600 & 200.0 & 34.8 & 9.9 & 12 & $(-)$ & 5120 & - & - & - & 0 & None & $30 \mathrm{mg} / \mathrm{day}$ \\
\hline \multirow[t]{2}{*}{5} & \multirow[t]{2}{*}{19} & \multirow[t]{2}{*}{$\mathrm{F}$} & 0.85 & 4520 & 920 & 311.0 & 27.2 & 1.9 & 13 & $(3+)$ & 320 & 15.60 & 3.54 & 2.24 & 21 & $1,2,4,5,8$ & None \\
\hline & & & 0.28 & 16130 & 1130 & 327.0 & 30.0 & 1.5 & 5 & $(1+)$ & 40 & 6.44 & 1.84 & 1.79 & 0 & None & $30 \mathrm{mg} /$ day \\
\hline 6 & 24 & $\mathrm{~F}$ & 0.25 & 8700 & 1400 & 149.0 & 34.2 & 1.5 & 185 & $(2+)$ & 5120 & 11.34 & 3.33 & 0.90 & 2 & None & $50 \mathrm{mg} /$ day \\
\hline 7 & 53 & $\mathrm{~F}$ & 0.40 & 5600 & 1200 & 13.0 & 36.2 & 1.5 & 5 & $(2+)$ & 160 & 18.24 & 6.00 & 0.79 & 1 & None & $60 \mathrm{mg} /$ day \\
\hline 8 & 39 & $\mathrm{~F}$ & 0.05 & 6800 & 1300 & 248.0 & 35.6 & 1.9 & 5 & $(-)$ & 40 & 9.80 & 2.09 & 0.55 & 0 & None & $15 \mathrm{mg} /$ day \\
\hline 9 & 41 & $\mathrm{~F}$ & 0.18 & 12400 & 400 & 247.0 & 47.6 & 1.6 & 5 & $(1+)$ & 640 & 13.13 & 2.73 & 0.51 & 0 & None & $20 \mathrm{mg} /$ day \\
\hline 10 & 36 & $\mathrm{~F}$ & 0.06 & 7900 & 1400 & 209.0 & 41.0 & 1.5 & 12 & $(-)$ & 80 & 11.89 & 1.71 & 0.88 & 0 & None & $5 \mathrm{mg} /$ day \\
\hline 11 & 56 & $\mathrm{~F}$ & 0.04 & 7900 & 1200 & 219.0 & 41.5 & 1.5 & 5 & $(1+)$ & 40 & 12.19 & 4.17 & 0.66 & 0 & None & $10 \mathrm{mg} /$ day \\
\hline 12 & 39 & $\mathrm{~F}$ & 0.10 & 5600 & 600 & 134.0 & 34.2 & 1.5 & 7 & $(3+)$ & 640 & 7.65 & 2.32 & 0.38 & 0 & None & $20 \mathrm{mg} /$ day \\
\hline 13 & 36 & $\mathrm{~F}$ & 0.58 & 9000 & 1100 & 138.0 & 24.0 & 1.5 & 21 & $(2+)$ & 320 & 16.53 & 3.55 & 1.39 & 4 & 7 & $30 \mathrm{mg} /$ day \\
\hline
\end{tabular}

WBC = white blood cell count $(/ \mu \mathrm{l}) ;$ Lymph. = lymphocyte count $(/ \mu \mathrm{l}) ;$ Plt. = platelet count $\left(\times 10^{3} / \mu \mathrm{l}\right) ; \mathrm{CH}_{50}=$ serum complement activity $(\mathrm{U} / \mathrm{ml}) ; \mathrm{IC}(\mathrm{C} 1 \mathrm{q})=$ serum immune complex level with a $\mathrm{C} 1 \mathrm{q}$ solid phase method $(\mu \mathrm{g} / \mathrm{ml})$,; dsDNA = anti-double stranded DNA antibody level (IU $/ \mathrm{ml})$; $\mathrm{u}$-prot. $=\mathrm{urine}$ protein analysis with a test paper method; ANA = antinuclear antibody (titre); IgG = immunoglobulin G level (g/l), IgA = immunoglobulin A level (g/l); IgM = immunoglobulin $\mathrm{M}$ level $(\mathrm{g} / \mathrm{l}) ; \mathrm{SLEDAI}=\mathrm{SLE}$ disease activity index.

Symptom: $1=$ central nervous system lupus; $2=$ arthritis; $3=$ myositis; $4=$ nephritis; $5=$ new rash; $6=$ alopecia; $7=$ serositis; $8=$ fever 
3 Weng N, Levine BL, June CH, Hodes RJ. Regulated expression of telomerase activity in human T lymphocyte development and activation. J Exp Med 1996;183:2471-9.

4 Bodnar AG, Kim NW, Effros RB, Chiu CP Mechanism of telomerase induction during $\mathrm{T}$ cell activation. Exp Cell Res 1996;228:58-64.

5 Yamada O, Motoji T, Mizoguchi H. Up regulation of telomerase activity in human lymphocytes. Biochim Biophys Acta 1996; 1314:260-6.

6 Weng N, Levine BL, June CH, Hodes RJ. Regulation of telomerase RNA template expression in human T lymphocyte development and activation. J Immunol 1997;158:3215-20.

7 Igarashi H, Sakaguchi N. Telomerase activity is Igarashi $\mathrm{H}$, Sakaguchi $\mathrm{N}$. Telomerase activity is induced in human peripheral B lymphocytes by the stimulation to antigen receptor. Blood

Katayama Y, Kohriyama K. Telomerase activity in peripheral blood mononuclear cells of systemic connective tissue diseases. J Rheumatol 2001;28:288-91.

\section{Treatment of ankylosing spondylitis with infliximab}

In January 2000 a 35 year old man presented with severe ankylosing spondylitis (AS), diagnosed in 1981. The Bath Ankylosing Spondylitis Disease Activity Index (BASDAI) was 6.0, the Bath Ankylosing Spondylitis Functional Index (BASFI) was 3.0, and on a 1-10 visual analogue scale (VAS) for pain in the previous two months he had a score of 6 .

Schober's test was $0 \mathrm{~cm}$ (normal $4 \mathrm{~cm}$ ), Ott's test $1 \mathrm{~cm}$ (normal $2 \mathrm{~cm}$ ), finger-floor distance $16 \mathrm{~cm}$, lateral flexion $3 \mathrm{~cm}$, traguswall distance $21 \mathrm{~cm}$, cervical rotation $30^{\circ}$.

C reactive protein (CRP) was $41 \mathrm{mg} / \mathrm{l}$ (normal $<5$ ), erythrocyte sedimentation rate (ESR) was $25 \mathrm{~mm} / 1 \mathrm{st} \mathrm{h}$ (normal <15), and HLA-B27 genotype was positive.

Conventional radiography showed typical signs of AS. Magnetic resonance imaging (MRI) detected inflammatory activity in the ileosacral joints ${ }^{1}$ by contrast enhancement after gadolinium application in the apical portion of the right ileosacral joint in $T_{1}$ weighted sequences (fig 1).

We started treatment with infliximab, ${ }^{2}$ a monoclonal antibody (IgG1) directed against tumour necrosis factor $\alpha(\mathrm{TNF} \alpha)$, at a dose of $5 \mathrm{mg} / \mathrm{kg}$ body weight. Intravenous infusions were given in weeks $0,2,6$, and then continued at six weekly intervals for one year without any additional disease modifying drug.

Pain improved within 24 hours of the first infusion. Within six weeks the patient required no ibuprofen and CRP, ESR, BASDAI, BASFI, and VAS improved dramatically (fig 2). With the exception of CRP and ESR, all variables remain normal up to now. CRP and ESR increased mildly at week 12 owing to a mild upper respiratory tract infection. There were no other adverse

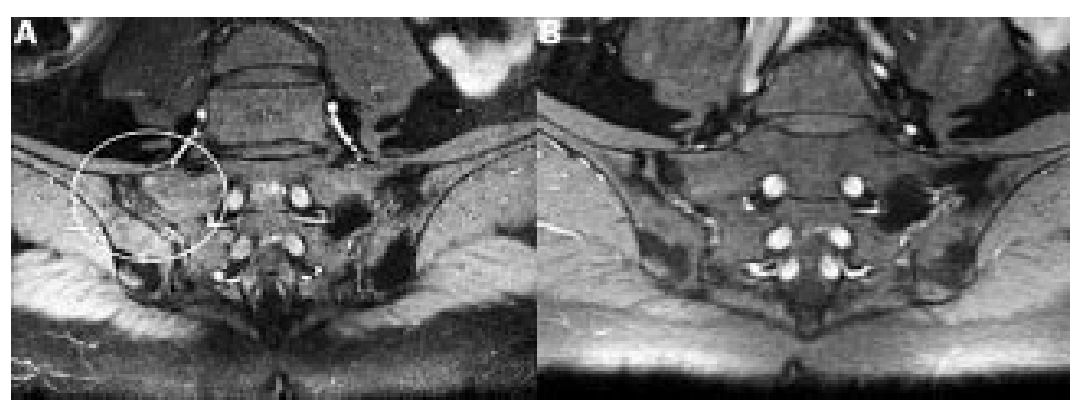

Figure 1 Gadolinium contrast enhanced $T_{1}$ weighted magnetic resonance imaging before treatment with infliximab (A) showing contrast enhancement in the right ileosacral joint, and (B) in week 41 of treatment showing no contrast agent uptake. events. Two mobility variables (cervical rotation and tragus-wall distance) had improved at the end of one year's treatment.

MRI of the ileosacral joints showed no contrast enhancement at weeks 14 and 41 of treatment (fig 1).

The patient denied any loss of effect at the end of the six weekly infusion intervals or after one year of treatment. Except for the mild upper respiratory tract infection, which abated after two weeks without specific treatment, there were no adverse events.

This case report documents the first long term application of infliximab in a patient with AS. Two previous studies reported
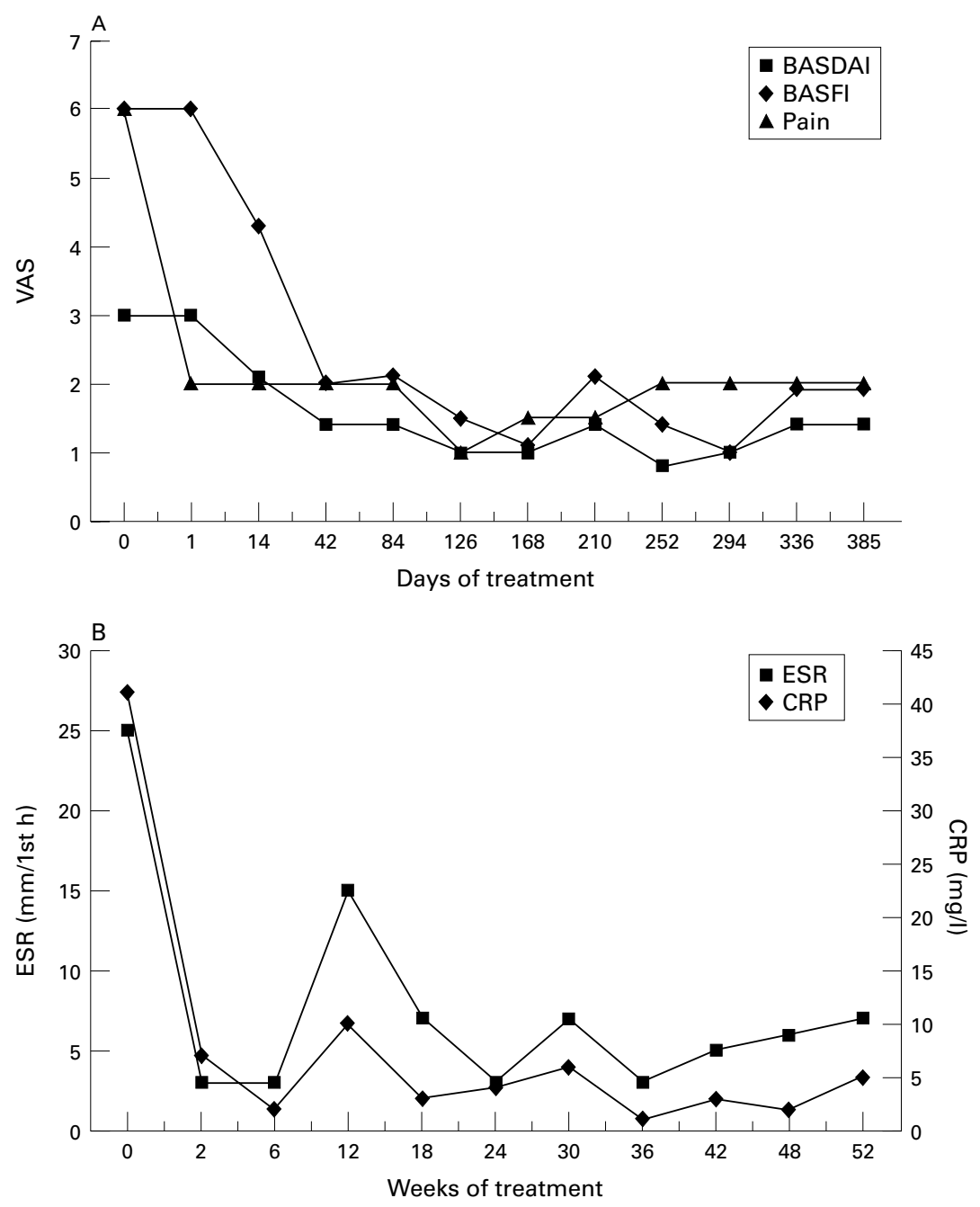

Figure 2 Self assessment of pain on a 1-10 visual analogue scale (A) and CRP and ESR (B).

effective treatment of a total of 22 patients with AS with three infusions of infliximab at a dose of $5 \mathrm{mg} / \mathrm{kg}$ body weight. ${ }^{34}$

The pharmacological basis for $\mathrm{TNF} \alpha$ inhibitory treatment in AS is the detection of $\mathrm{TNF} \alpha-\mathrm{mRNA}$ and $\mathrm{TNF} \alpha$ protein in biopsy specimens of ileosacral joints of patients with active $\mathrm{AS} .^{5}$ In rheumatoid arthritis (RA) and Crohn's disease (CD), several TNF $\alpha$ inhibitors seem to be successful in significantly reducing inflammatory activity. ${ }^{67}$

Theoretically, up regulation of the $\mathrm{TNF} \alpha$ receptors and subsequent tachyphylaxis might be expected upon constant blockade of the agonist. This has not been noted in studies on infliximab, etanercept, and D2E7 in $\mathrm{RA}, \mathrm{CD}$, and psoriatic arthritis (PA) during long term treatment, even when constant therapeutic plasma levels are maintained. ${ }^{7-9}$ This case report suggests this is true also for patients with AS.

In summary, we present the case of a patient with AS effectively and safely treated with infliximab over a period of more than one year. This indicates that treatment of AS with $\mathrm{TNF} \alpha$ inhibiting substances may have equal long term safety and long term benefits on peripheral and spinal joint function as does treatment of RA, CD, and PA. Randomised controlled double blind studies are needed to investigate this in further detail. 


\section{A BOEGER \\ H WITTWER \\ M SCHATTENKIRCHNER \\ H KELLNER \\ Rheumatology Unit, \\ Medizinische Poliklinik, Munich, Germany \\ W KELLNER \\ Radiological Institute, \\ Munich University Hospital, Germany}

Correspondence to: Dr C A Boeger, Rheumatology Unit, Medizinische Poliklinik, Pettenkoferstrasse 8a, 80336 Munich, Germany

carsten.boeger@gmx.net

1 Braun J, Bollow M, Eggens U, König H, Distler A, Sieper J. Use of magnetic resonance imagin with fast imaging in the detection of early and advanced sacroiliitis in spondylarthropathy patients. Arthritis Rheum 1994;37:1039-45.

2 Knight DM, Trinh H, Le J, Siegel S, Shealy D, McDonough $M$, et al. Construction and initial characterization of a mouse-human chimeric anti-TNF antibody. Mol Immunol 1993;30: 1443-53.

3 Brandt J, Haibel H, Cornely D, Golder W, Gonzalez J, Reddig J, et al. Successful treatment of active ankylosing spondylitis with the anti-tumor necrosis factor alpha monoclonal antibody infliximab. Arthritis Rheum 2000;43. 1346-52

4 Van den Bosch F, Kruithof E, Baeten D, De Keyser F, Mielants H, Veys EM. Effects of a loading dose regimen of three infusions of chimeric monoclonal antibody to tumour necrosis factor alpha (infliximab) in spondyloarthropathy: an open pilot study. Ann Rheum Dis 2000;59:428-33.

5 Braun J, Bollow M, Neure L, Seipelt E, Seyrekbasan $\mathrm{F}$, Herbst $\mathrm{H}$, et al. Use of immunohistologic and in situ hybridisation techniques in the examination of sacroiliac joint biopsy specimens from patients with ankylosing spondylimens from patients with ankylosing sp
tis. Arthritis Rheum 1995;38:499-505.

6 Maini R, St Clair EW, Breedveld F, Furst D, Kalden J, Weisman $\mathrm{M}$, et al. Infliximab (chimeric anti-tumor necrosis factor alph monoclonal antibody) versus placebo in rheumatoid arthritis patients receiving concomitan methotrexate: a randomised phase III trial ATTRACT Study Group. Lancet 1999;354: 1932-9.

7 Present DH, Rutgeerts P, Targan S, Hanauer SB, Mayer L, van Hogezand RA, et al. Infliximab for the treatment of fistulas in patients with Crohn's disease. N Engl J Med 1999;340:1398-405.

8 Kremer JM, Spencer-Green GT, Hanna RK, Korth-Bradley JM. Enbrel@ (etanercept) pharmacokinetics in patients with rheumatoid arthritis. Arthritis Rheum 2000;43(suppl): arthritis.
abstr 976 .

9 Schattenkirchner M, Wastlhuber J, Rau R, Herborn G, Kroot EJ, van Riel PLCM, et al. Longborn G, Kroot EJ, van Riel PLCM, et al. Long-
term use of the fully human anti-TNF term use of the fully human anti-TNF
antibody D2E7 in combination with methoantibody D2E7 in combination with metho-
trexate in active rheumatoid arthritis. Arthritis Rheum 2000;43(suppl):abstr 968.

\section{Retrocalcaneal bursitis in polymyalgia rheumatica}

Polymyalgia rheumatica (PMR) is a relatively common disease of the elderly affecting the synovial membrane.

Recent studies have emphasised the prominent involvement of the extra-articular synovial structures in both proximal and distal regions of both the arms and legs. ${ }^{1-7}$ In the distal part of the arms tenosynovial membrane inflammation is responsible for carpal tunnel syndrome, distal swelling of hands and feet with or without pitting oedema, and localised episodes of distal tenosynovitis. ${ }^{4}$

We recently observed the case of a patient with PMR showing retrocalcaneal bursitis, which we describe briefly here.

A 68 year old woman was referred to us for evaluation of a three month history of marked aching and morning stiffness in her neck, shoulder, and hip girdles associated with low grade fever. Her medical history was otherwise unremarkable except for a hereditary cerebellar cortical degeneration. Her family history was negative for rheumatic diseases, including spondarthritis.

Physical examination showed tenderness and limitation of cervical and shoulder movement. The typical gait and abnormal stance of cerebellar ataxia were also present.

Laboratory evaluation disclosed an erythrocyte sedimentation rate (ESR) of 72 $\mathrm{mm} / 1 \mathrm{st} \mathrm{h}$ (Westergren) and a $\mathrm{C}$ reactive protein (CRP) concentration of $80 \mathrm{mg} / 1$ (normal $<5)$. Tests for rheumatoid factor, antinuclear antibodies, and serum tumour markers were negative, and HLA typing did not show the B27 antigen.

Methylprednisolone at a dose of $16 \mathrm{mg} /$ day was started and symptoms rapidly disappeared. ESR and CRP were normal after one month of treatment.

Nine months after starting treatment, when the dose of methylprednisolone was 6 $\mathrm{mg}$ /day, the patient experienced pain in her shoulder girdle and right foot. Physical examination showed an enlarged and painful right retrocalcaneal bursa. There was no pain and swelling along her right Achilles tendon and at its calcaneal insertion. Magnetic resonance imaging (MRI) showed an enlarged retrocalcaneal bursa without any sign of Achilles tendonitis or enthesitis (fig 1). An anteroposterior view of her pelvis showed normal sacroiliac joints. Both shoulder girdle symptoms and retrocalcaneal bursitis disappeared promptly when the dose of methylprednisolone was increased and have not reappeared so far, 12 months after discontinuation of treatment.

Our patient had PMR and showed retrocalcaneal bursitis as a distal manifestation of the disease.

The prominent involvement of the extraarticular synovial structures in both the
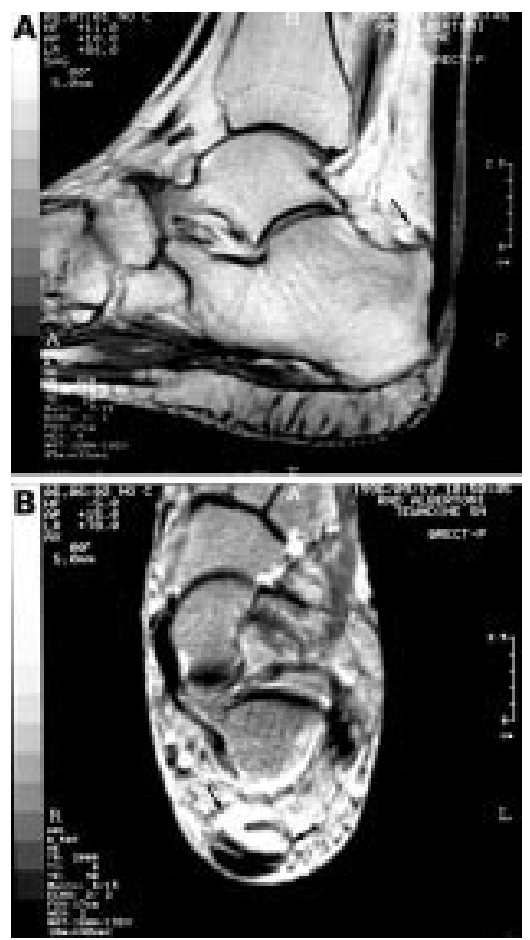

Figure 1 Sagittal $T_{1}(A)$ and axial $T_{2}(B)$ weighted images of the left Achilles tendon showing the distension of the retrocalcaneal bursa by fluid collection (arrows) together with normal Achilles tendon and enthesis. peripheral and distal inflammatory processes of PMR has only recently been demonstrated. ${ }^{2-7}$ The distal manifestations of PMR include tenosynovitis in addition to joint synovitis. ${ }^{14-7}$ Extensor tenosynovial sheath involvement, which may give swelling with pitting oedema over the dorsum of the hands and feet, is common and has been recorded by MRI. ${ }^{4-7}$ Tenosynovitis under the transverse carpal ligament may cause carpal tunnel syndrome. ${ }^{7}$ The involvement of hand flexor, posterior tibial and peroneal tendons may occur and has been documented with MRI. ${ }^{1457}$

To the best of our knowledge retrocalcaneal bursitis has never been reported in patients with PMR. Chuang et al found "bursitistendinitis" in 48/96 (50\%) patients with PMR. ${ }^{8}$ Although they considered these as part of the disease, no mention of the affected bursae was made in their article. Possibly, some of the 48 patients developed retrocalcaneal bursitis. The retrocalcaneal bursa differs from other deep bursae, such as the subacromial and subdeltoid bursa and the gastrocnemiussemimembranous bursa. ${ }^{9}$ The synovial membrane is present only at its roof while its anterior wall is fibrocartilage layered onto the calcaneus and its posterior wall sesamoid fibrocartilage differentiated in the Achilles tendon. This anatomical arrangement makes the bursa an integral part of the Achilles enthesis. In spondarthritis, which is a disease of the entheses, retrocalcaneal bursitis often occurs in association with Achilles enthesitis. ${ }^{10}$ In contrast, retrocalcaneal bursitis tends to occur in isolation in rheumatoid arthritis, suggesting that the synovial membrane at the top is the primary site of inflammation. ${ }^{9}$ The same may be valid for PMR. Our patient had no clinical sign of Achilles tendon involvement and MRI showed no sign of enthesitis, that is to say, tendon swelling and bone oedema.

In conclusion our report suggests that the synovial membrane of distal bursae may also be affected in PMR.

I OLIVIERI A PADULA

Dipartimento di Reumatologia della Lucania, Ospedale San Carlo, Potenza, Italy

C SALVARANI Divisione di Reumatologia, Arcispedale Santa Maria Nuova, Reggio Emilia, Italy F CANTINI Unità di Reumatologia, Divisione di Medicina, Ospedale di Prato, Italy

L BAROZZI Servizio di Radiologia Albertoni, Ospedale S Orsola-Malpighi, Bologna, Italy

Correspondence to: Dr I Olivieri, Rheumatology Department of Lucania, Ospedale San Carlo, Contrada Macchia Romana, 85100 Potenza, Italy

\section{ignazioolivieri@tiscalinet.it}

1 Salvarani C, Cantini F, Olivieri I, Hunder GG Polymyalgia rheumatica: a disorder of extraa ticular synovial structures? J Rheumatol 1999;26:517-21.

2 Salvarani C, Cantini F, Olivieri I, Barozzi L, Macchioni L, Niccoli L, et al. Proximal bursitis in active polymyalgia rheumatica. Ann Intern Med 1997;127:27-31.

3 Cantini F, Salvarani C, Olivieri I, Niccoli L, Padula A, Bozza A. Hip bursitis in active polymyalgia rheumatica: report of a case. Clin Exp myalgia rheumatica: report of

4 Salvarani C, Gabriel S, Hunder GG. Distal extremity swelling with pitting edema in extremity swelling with pitting edema in
polymyalgia rheumatica. Report of nineteen cases. Arthritis Rheum 1996;39:73-80. 
5 Salvarani C, Cantini F, Macchioni L, Olivieri I, Niccoli L, Padula A, et al. Distal musculoskelA prospective follow-up study. Arthritis Rheum A prospective follow
1998;41:1221-6.

6 Cantini F, Salvarani C, Olivieri I, Barozzi L, Macchioni L, Niccoli L, et al. Remitting seronegative symmetrical synovitis with pitting oedema syndrome: a prospective follow up study and magnetic resonance study. Ann Rheum Dis 1999;58:230-6.

7 Salvarani C, Hander GG. Musculoskeletal manifestations in a population-based cohort of patients with giant cell arteritis. Arthritis Rheum 1999;42:1959-66.

8 Chuang T-Y, Hunder GG, Ilstrup DM, Kurland LT Polymyalgi rheumatica: a 10-year epideLT. Polymyalgia rheumatica: a 10-year epide1982;97:672-80.
9 Canoso J. The premiere enthesis. J Rheumatol 1998;25:1254-6.

10 Olivieri I, Barozzi 1, Padula A, De Matteis M, Pierro A, Cantini F, et al. Retrocalcaneal bursitis in spondylarthropathy: assessment by ultrasonography and magnetic resonance imaging. J Rheumatol 1998;25:1352-7.

\section{CORRECTION}

Comorbidity and lifestyle, reproductive factors, and environmental exposures associated with rheumatoid arthritis (Reckner Olsson A, Skogh T, Wingren G. Ann Rheum Dis 2001;60:934-9.)

The authors regret that an error is present in the fourth paragraph of the "Results" section. The first sentence should read: "A nonsignificant increased risk of RA was seen in both men and women who consumed at least $75 \mathrm{ml}$ of alcohol per drinking session at the age of 25 compared with total abstainers" and not " $750 \mathbf{~ m l " ~ a s ~ s t a t e d . ~}$

(Note: Corrections printed in the journal also appear on the Annals web page (www. annrheumdis.com) and are linked to the original publication.)

\section{EULAR training bursaries}

Up to 10 scholarships for clinical or laboratory work (3-6 months) in a foreign unit will be made available for applicants from countries where there is a clear educational need.

The value of each bursary is 7000 euros. Candidates should be under 35 years of age and the grant will not be made if the applicant is already abroad in training.

A curriculum vitae, a statement of qualification, a project outline, and a written confirmation from the host hospital that training is possible must be received at the EULAR Secretariat no later than 28 February 2002.

\section{EULAR prize}

The prize, to the value of 30000 euros, is awarded by EULAR for an outstanding contribution in the field of rheumatology in recent years.

The competition is open to both scientists and clinicians working in the field of rheumatology. The prize will be awarded for the work of a group and not to an individual person.

The documents submitted in support of an entry may take the form of an essay or a description of the project. The prize will not be awarded for a publication or an abstract.

The essay with the CV of the head of the group and a publication list must be received at the EULAR Secretariat in Zurich no later than 28 February 2002.

\section{EULAR young investigator awards}

Three awards for a scientific (clinical or basic) research project of 30000 euros each, will be made available for laboratory/research work in the field of rheumatology.

Candidates must submit a project outline, a CV, and expense budget and should be under 35 years of age.

Entries for the Young Investigator Awards must be received at the EULAR Secretariat in Zurich no later than 28 February 2002.

\section{AMGEN/EULAR young investigator award}

AMGEN (Europe) will make an award of 30000 euros for a scientific (clinical or basic) research project in the area of rheumatoid arthritis. The prize money is intended to support laboratory/research work.

Candidates must submit a project outline, a CV, and expense budget and should be under 35 years of age.

Entries for the award must be received at the EULAR Secretariat in Zurich no later than 28 February 2002.

\section{Endowment of the awards}

The EULAR prize, the EULAR young investigator awards, and the AMGEN/EULAR young investigator award will be endowed at the opening ceremony of the Annual European Congress of Rheumatology to be held in Stockholm, Sweden, on 12 June 2002.

\section{www.eular.org}

Bursaries, the EULAR prize, and the Young Investigator Awards are also announced on www.eular.org

Applications should be forwarded to:

EULAR Executive Secretariat, Witikonerstrasse 15, CH-8032 Zurich, Switzerland

Tel: + 41138396 90; fax: + 41138398 10; email: secretariat@eular.org 